\title{
The Freedom of Intimate Association
}

\author{
Kenneth L. Karst*
}

The last words of Justice Douglas's remarkable opinion for the Court in Griswold v. Connecticut ${ }^{1}$ were these:

Marriage is a coming together for better or for worse, hopefully enduring, and intimate to the degree of being sacred. It is an association that promotes a way of life, not causes; a harmony in living, not political faiths; a bilateral loyalty, not commercial or social projects. Yet it is an association for as noble a purpose as any involved in our prior decisions. ${ }^{2}$

At first reading, these comments seemed not so much a peroration as an afterthought, an effort to draw additional support for the Court's decision from a series of precedents protecting the freedom of political association. ${ }^{3}$ Characteristically, Justice Douglas was content to be suggestive, and to leave to others the task of doctrinal elaboration.

Before Griswold was decided, the notion of constitutional protection of the freedom of association was a First Amendment doctrine and little more. ${ }^{4}$ Yet Griswold's focus was not someone's right to give or receive information about contracéption, but the right of a married couple to use devices that would accomplish it. The Court's opinion located that right within a generalized "zone of privacy," created in part by the First Amendment, but by the Third, Fourth, and Fifth

- Professor of Law, University of California, Los Angeles. I am grateful to a small regiment of my UCLA colleagues, and to the members of Yale's Legal Theory Workshop, for their valuable comments on a draft of this Article. In particular, I want to thank my colleague Steven Shiffrin for long hours of discussion, for helpful analysis, and for unfailing encouragement.

I. 381 U.S. 479 (1965).

2. Id. at 486 .

3. The cases Justice Douglas cited were NAACP v. Button, 371 U.S. 415 (1963); NAACP v. Alabama, 357 U.S. 449 (1958); and Schware v. Board of Bar Examiners, 353 U.S. 232 (1957).

4. See, e.g., Emerson, Freedom of Association and Freedom of Expression, 74 YALE L.J. 1, 20-21 (1964) (fleeting reference to "personal associations"); Fellman, Constitutional Rights of Association, 1961 Sup. CT. Rev. 74. But cf. C. RICE, Freedon of Association (1962) (including chapter on labor organizations); Wechsler, Toward Neutral Principles of Constitutional Law, 73 HARv. L. REv. 1, 34 (1959) (explaining school desegregation as problem of conflicting associational freedoms). See generally Raggi, An Independent Right to Freedom of Association, 12 HARv. C.R.-C.L. L. REv. 1, 2-11 (1977). 
Amendments as well. 5 Whatever the constitutional right of privacy may mean in other contexts, the main object of constitutional protection in Griswold was the marital relationship.

If Griswold has prevented any children from being conceived, none of the children-who-weren't would yet be fifteen years old. During this short time, the Supreme Court has decided about fifty cases ${ }^{6}$ dealing with marriage and divorce, family relationships, the choice whether to procreate, ${ }^{7}$ and various forms of intimate association outside the traditional family structure. There is luxuriant variety in the factual contexts of these cases, which range from illegitimacy to the right to marry, from communes to homosexual association. Doctrinally, too, the cases reflect various hues on the constitutional spectrum. Some are discussed in equal protection terms; others inspire the rhetoric of due process, either procedural or substantive. Yet, for all their diversity, these decisions can usefully be seen as variations on a single theme: the freedom of intimate association.

Perhaps because of its origins in the least stable terrain of modern constitutional doctrine, the freedom of intimate association still has a pliable quality, inviting question-begging and the manipulation of circular arguments. The Supreme Court has not yet given explicit articulation to this freedom, or delineated with any clarity either its scope or the justifications for its limitation. Although it may still be too early for a thorough-going doctrinal synthesis, however, the need for analysis is clear. I begin, therefore, by defining the freedom of intimate association and identifying and exploring the values that may be at stake when that freedom is asserted. Two subsidiary points will occupy us next: the connection between these values and the freedom of associational choice, and some puzzling interrelations of associational choice with formal associational status and related material benefits. With these analytical tasks behind us, we turn to the constitutional doctrines that have nurtured the freedom of intimate association: the First Amendment, equal protection, and substantive due process.

The last part of the Article is a lawyer's exercise. I examine the ways in which the nascent freedom serves as an organizing principle

5. 381 U.S. at 484 . State law could not constitutionally forbid the use of contraceptives, for the marriage relationship lay within the zone of privacy and the law would have "a maximum destructive impact upon that relationship." $I d$. at 485 .

6. This number includes only those cases decided with full opinions.

7. The precursor of these decisions, of course, was Skinner v. Oklahoma, 316 U.S. 535 (1942), in which the Court held that Oklahoma's habitual criminal sterilization act violated equal protection guarantees. 
in a number of associational contexts. In all these areas of human relationship, we shall see that the freedom of intimate association informs judgment by focusing attention on the substantive associational values at stake in particular classes of cases. ${ }^{8}$

\section{The Freedom of Intimate Association}

Because the freedom of association is an ancient idea in political philosophy, ${ }^{9}$ and even an old topic of commentary on American public life, ${ }^{10}$ it is fair to ask why the subject of intimate association deserves separate treatment. Part of the justification is historical. Much of the doctrinal ferment in this area appears closely related to an egalitarian trend visible throughout the industrialized West, ${ }^{11}$ and nowhere more clearly than in American constitutional law. We have been led to a new appreciation and acceptance of cultural diversity, and to a reexamination of the place of women in society. Both these developments have contributed to the seismic emergence of the freedom of intimate association as a feature in our constitutional landscape.

The most important justification, however, is practical. Griswold was part of a larger doctrinal movement: the revival of substantive due process as a guarantee of individual freedoms. The freedom of intimate association is one of this movement's early products. The judicial decisions on this subject hold out some promise of doctrinal coherence, shaped around similarities in the values at stake in the various cases; the constitutional freedom of intimate association thus serves as an organizing principle ${ }^{12}$ in a number of associational contexts by promoting awareness of the importance of those values to the development of a sense of individuality. ${ }^{13}$ The Supreme Court has not yet articulated this freedom explicitly, but the freedom's

8. There is a tension in this Article-as in most writing that addresses emerging legal doctrines-between advocating the recognition of a "new" freedom and arguing that it is a freedom already protected sub silentio. Certainly that was a concern of Samuel Warren and Louis Brandeis when they identified a right of privacy. Warren \& Brandeis, The Right to Privacy, 4 Harv. L. Rev. 193 (1890). In this Article, I contend that the Court should acknowledge a presumptive freedom of intimate association, see pp. 627-29 infra, but $I$ also argue that a concern to protect this freedom lies behind many of the Supreme Court's recent decisions in the areas of marriage, procreation, and parent-child relations.

9. See C. Rice, supra note 4, at 1-18; MAX WEBER ON LAW IN ECONOMY AND SOCIETY 154-91 (M. Rheinstein ed. 1954).

10. See C. Rice, supra note 4, at 19-41; A. De Tocqueville, Democracy in America (1904; 1st ed. 1835).

11. See generally R. Aron, Progress And Disillusion 68-72 (1968).

12. The freedom of intimate association is a particularized version of what Owen Fiss calls a "mediating" principle. See Fiss, Groups and the Equal Protection Clause, 5 PHILOSOPHX \& Pub. AFF. 107, 107-08 (1976).

13. See R. Unger, Knowledge and Politics 213-22, 262-65 (1975); cf. Benn, Privacy, Freedom, and Respect for Persons, in Nomos XIII, PrIvacY 1 (R. Pennock \& J. Chapman 
emergence can be seen in the Court's decisions on such subjects as marriage, the decision whether to procreate, legitimacy of parentage, and parent-child relations. Not surprisingly, the Court has only barely begun to delineate the scope of the freedom and the justifications for its limitation.

The freedom of intimate association, like other constitutional freedoms, is presumptive rather than absolute. In particular cases, it may give way to overriding governmental interests. ${ }^{14}$ The freedom does not imply that the state is wholly disabled from promoting majoritarian views of morality. ${ }^{15}$ What the freedom does demand is a serious search for justifications by the state for any significant impairment of the values of intimate association. And, like the First Amendment, which is one of its doctrinal underpinnings, it rejects as illegitimate any asserted justification for repression of expressive conduct based on the risk that a competing moral view will come to be accepted. Because different governmental actions will invade the values of intimate association in different degrees, the influence of this freedom will vary from one case to the next.

The freedom of intimate association is thus a principle that bears on constitutional interest balancing by helping to establish the weight to be assigned to one side of the balance. In recent years, the Supreme Court frequently has accomplished this task through its selection of the appropriate standard of review. Marriage, for example, is a "fundamental freedom," 16 and state laws significantly interfering with the decision to marry must pass the test of "rigorous scrutiny."17 Similarly, governmental intrusions on "choices concerning family liv-

eds. 1971) [hereinafter cited as Privacy]. The recognition of the relational values of intimate association is the main justification for treating this particular freedom separately, rather than lumping it indiscriminately with other freedoms to behave in ways that arguably do not harm others, such as smoking marijuana.

14. Similarly, the First Amendment freedom of political association is a presumptive guarantee that may give way, in particular cases, to overriding governmental interests. See, e.g., Scales v. United States, 367 U.S. 203 (1961) (upholding conviction for active, purposive membership in organization engaged in illegal advocacy).

15. The literature on governmental enforcement of morals is enormous and still grow. ing. Even in the subject areas of this Article's focus, however, most writers have given their main attention to the legitimacy of various justifications offered when the state imposes sanctions on disfavored lifestyles or intimate relations that deviate from majoritarian preferences. See, e.g., Gelfand, Authority and Autonomy: The State, the Individual and the Family, 33 U. Miam L. REv. 125 (1978); Wilkinson \& White, Constitutional Protection for Personal Lifestyles, 62 CoRNELL L. REv. 563 (1977). For citations to some leading discussions, see Richards, Sexual Autonomy and the Constitutional Right to Privacy: A Case Study in Human Rights and the Unwritten Constitution, 30 Hastincs L.J. 957, 990-99 (1979). In this Article I do not reexamine these questions of officially sponsored morality in any systematic way.

16. Loving v. Virginia, 388 U.S. 1, 12 (1967).

17. Zablocki v. Redhail, 434 U.S. 374,386 (1978). 
ing arrangements" must undergo strict scrutiny. ${ }^{18}$ Laurence Tribe's formulation is both a summary of some of these developments and a prescription: "[T] $\mathrm{T}$ he embedding of a choice within a close human relationship or network of relationships should always be regarded as significantly increasing the burden of justification for those who would make the choice illegal or visit it with some deprivation."10

Neither the Supreme Court's standard-of-review selections nor Professor Tribe's precept demand the strictest form of "strict scrutiny" every time a governmental regulation touches intimate association, however. The Court's decisions properly recognize that some regulations press more heavily on associational choices than do others. In the intimate association cases, as elsewhere in the Court's recent constitutional jurisprudence, the order of the day is a "sliding scale" of standards of review-that is, an increasingly candid interest balancing. ${ }^{20}$ The freedom of intimate association serves its organizing function by helping a court to decide how much the state's burden of justification should be increased when its regulation limits the choice of intimate associations, by focusing inquiry on the particulars of the associational values in the type of case at hand.

The interests ranged against the claim of associational freedom are by no means limited to the exigencies of the material world. Thus the state may claim a role in socializing its citizens, especially the young, to traditions of authority, stability, and fidelity. In particular, legislative majorities have sought to promote traditional views about marriage, procreation, and family relationships-and, correspondingly, to dissuade people from entering into informal unions or homosexual relationships, or from practicing contraception or abortion. Moreover, in a variety of ways, governments have conditioned transfer payments and other entitlements on certain forms of intimate associational status. Indeed, the type of case that most frequently raises issues of the freedom of intimate association involves a claim to some material benefit. ${ }^{21}$ Can a board of education refuse to hire a teacher because he is a homosexual?22 Can a woman be denied admission to the bar because she is living with a man who is not her husband? ${ }^{23}$ Can wel-

18. Moore v. City of East Cleveland, 431 U.S. 494,499 (1977) (plurality opinion of Powell, J.).

19. L. Tribe, American Constitutional Law 989 (1978) (italicized in original).

20. See Karst, The Supreme Court, 1976 Term-Foreword: Equal Citizenship Under the Fourteenth Amendment, 91 HARv. L. REv. 1, 42 \& $n .226$ (1977).

21. See pp. 647-52 infra.

22. Gaylord v. Tacoma School Dist. No. 10, 88 Wash. 2d 286, 559 P.2d 1340, cert. denied, 434 U.S. 879 (1977).

23. See Cord v. Gibb, Va. 254 S.E.2d 71 (1979). 
fare benefits be denied to a family when a "substitute father" is living in the house?"24 Of course, some denials of benefits will impair the values of freedom of intimate association more than others. To say that the freedom of intimate association is to be placed in the balance does not tell us how much it weighs in a given case.

That question can be answered only through patient examination of the ways in which the values of intimate association are affected by the type of governmental action before the court. Indeed, the main point of this Article is that guidance is to be found in the perception that claims to the freedom of intimate association, arising in disparate factual contexts, are nonetheless characterized by a series of common and overlapping values.

\section{The Values of Intimate Association}

By "intimate association" I mean a close and familiar personal relationship with another that is in some significant way comparable to a marriage or family relationship. An intimate association, like any group, is more than the sum of its members; it is a new being, a collective individuality with a life of its own. ${ }^{25}$ Some of the primary values of intimate association depend on this sense of collectivity, the shared sense that "we" exist as something beyond "you" and "me." The connecting links that distinguish such an association from, say, membership in the PTA may take the form of living in the same quarters, or sexual intimacy, or blood ties, or a formal relationship, or some mixtures of these, but in principle the idea of intimate association also includes close friendship, with or without any such links. ${ }^{28}$

Why do we prize the freedom of intimate association? What values are impaired if that freedom is restricted? In a world ordered by logic, we might expect such questions to be asked and answered before legal doctrine took shape. In our not-so-tidy world of constitutional

24. E.g., King v. Smith, 392 U.S. 309 (1968). Just to enumerate these legal questions would take us through a cross-section of issues for a college course on "The Family in Transition." See generally A. Skolnick \& J. Skolnick, Family in Transition (1971).

25. See E. Durkheim, The Rules of Sociological Method 103 (S. Salovay \& J. Mueller transl. 8th ed. 1938).

26. Friendship does not involve the degree of exclusivity that is present in the other kinds of linkage between intimates, and might arguably be separated for analytic purposes. The law, of course, largely ignores relationships among friends, but it is plain that the values of intimate association may be realized in friendships involving neither sexual intimacy nor family ties. Any view of intimate association focused on associational values must therefore include friendship, and some of the cases discussed in this Article do permit us to see the potential applications to cases of friendship. See pp. 687-89 infra. 
law, the sequence is typically just the reverse; the Griswold decision itself is a page of history in point. Even the subsequent commentary has tended to avoid analyzing the values in intimate association, and to focus instead on the justifications for its restriction ${ }^{27}$ or on questions of judicial methodology. ${ }^{28}$ The discussion that follows is an effort to ask some substantive questions that are logically prior.

\section{A. An Illustrated Catalogue}

There is a risk in an excursus like this, roughly comparable to the risk in pursuing literally the inquiry, "How do I love thee? Let me count the ways." 29 The joys and beauties (or, for that matter, the pains) of intimate association are not really reducible to entries on a shopping list, even a list headed "Values." As the reader has guessed, though, that recognition isn't going to stop me.30

\section{Society}

The simplest and most obvious value embraced in the idea of intimate association is the opportunity to enjoy the society of certain other people. The statement is not tautological. There are forms of association that do not require even the acquaintance of one associate with the rest: ownership of corporate shares, for example, or membership in the American Civil Liberties Union. Intimate association, however, implies an expectation of access of one person to another particular person's physical presence, some opportunity for face-to-face encounter. ${ }^{31}$ Such encounters are always discontinuous, at least in our urban society; they may be fleeting, or they may be regular and frequent. The idea of a freedom of intimate association thus includes a couple's claim of the right to choose to live together, with or without a sexual relationship, but it also includes a divorced

27. E.g., Gelfand, supra note 15; Wilkinson \& White, supra note 15.

28. E.g., Kauper, Penumbras, Peripheries, Emanations, Things Fundamental and Things Forgotten: The Griswold Case, 64 Mich. L. REv. 235 (1965).

29. E.B. Browning, Sonnets from the Portuguese XLIII (1850).

30. A few cautionary words are in order, however. This is a survey of potential values in intimate association, not an inventory of universals. Moreover, the various elements in my list overlap each other at many points. Finally, an omission from this survey may seem to glare. One value of intimate association may be an expectation of mutual material support, and one way the state may burden the freedom of intimate association is to restrict access to some material benefit. These material concerns will come to the foreground when we consider the subject of formal associational status. See pp. 647-52 infra.

31. It is possible to lose someone's society without losing face-to-face contact, as in the case of the old British labor union practice of "sending to Coventry"-not speaking to a co-worker who fails to cooperate with the union. 
mother's claim of a right to access to her child who is in the custody of her former husband, or a prisoner's claim of a right to be visited occasionally by family and friends.

The common law has long considered this interest in the society or companionship of an intimate associate as basic. The interest in a spouse's consortium is a familiar example..$^{32}$ Habeas corpus and the tort of false imprisonment are premised on the assumption, usually well-founded, that imprisonment is harmful. Part of that harm consists of the prisoner's being deprived of the society of his family and friends, and thrust against his will into humiliatingly close association with other prisoners. ${ }^{33}$

The denial of the society of an intimate may be partial, as in the case of a parent who loses a contest over child custody but is allowed visitation rights, or virtually total, as when a noncustodial parent is denied visitation rights. The denial of another's society may be permanent, as when a baby is given up for adoption and all the records are sealed, or temporary, as in the case of a short jail sentence. Access may be denied directly, either by physical barriers or by the law's prohibition, ${ }^{34}$ or indirectly, as when government offers a benefit only when the beneficiary gives up another's association. In short, even the simplest feature of the freedom of intimate association-the opportunity for the society of other people-turns out to be a substance with varying textures and densities.

Anyone who is not a hermit values the society of many people other than intimates, of course, such as co-workers or casual friends. The loss of an intimate's society takes on special importance because it also entails the loss of opportunities to realize other values of intimate association.

32. At common law, this interest was narrowly defined to include only a husband's right of sexual access to his wife. Modern law has tended to downplay the sexual aspect of the interest in consortium, and to extend the interest to wives as well as husbands. See W. Prosser, Torts 888-97 (4th ed. 1971); cf. Morrison v. Jones, 607 F.2d 1269 (9th Cir. 1979) (mother's familial rights may be violated when county officials cause her minor son to be transported to Germany to live with his grandparents).

33. See, e.g., E. Goffman, Asylums (1961). As Goffman shows, similar consequences flow from commitment to mental hospitals. On prison visits, see Jacobs \& Steele, Sexual Deprivation and Penal Policy, 62 CoRnell L. Rev. 289 (1977); Note, On Prisoners and Parenting: Preserving the Tie that Binds, 87 YALE L.J. 1408 (1978). Compare White v. Keller, 588 F.2d 913 (4th Cir. 1978), aff'g 438 F. Supp. 110 (D. Md. 1977) (no right to due process hearing before prison visitation rights can be restricted) with Valentine v. Englehardt, 474 F. Supp. 294 (D.N.J. 1979) (holding county jail procedures totally barring visitation by inmates' children unconstitutional under Eighth and Fourteenth Amendments).

34. The latter is exemplified by an injunction forbidding a man from persisting in trying to see his former wife. 


\section{Caring and Commitment}

To avoid groping for explanations in Skinner boxes of genetic codes, let us assume that to be human is to need to love and be loved. ${ }^{35}$ For most of us, the chief value in intimate association is the opportunity to satisfy these needs. ${ }^{36}$ Of course, there are no guarantees. If anyone's individual experience needs confirmation, we have the testimony of novelists, philosophers, and psychiatrists that families and marriages and other intimate associations, lasting or casual, also offer opportunities to suffer the guilt of exploitation, the anxiety of dependency, and all the related angers and agonies of power relationships. ${ }^{37}$ Still, the ideal remains, and most people who abandon particular intimate associations soon form new ones. ${ }^{38}$

The opportunity to be cared for by another in an intimate association is normally complemented by the opportunity for caring. ${ }^{30}$ Since caring for an intimate implies a patient effort to know him, trust him, hope for him, and help him develop, it implies commitment to the other. ${ }^{40} \mathrm{I}$ use the word "commitment" to denote not a legal commitment (a promise enforceable by law), but a personal commitment, the sense that one is pledged to care for another and intends to keep the pledge. ${ }^{41}$

Two aspects of commitment are especially relevant in evaluating

35. For somewhat cooler views, see B. Skinner, Science and Human Behavior 160-70 (1953); E. Wilson, ON Human Nature 121-67 (1978); E. Wilson, Sociobiology 106-29, 314-52 (1975); Harlow, The Nature of Love, 13 AM. PsYchologist 673 (1958); Harlow \& Suomi, Nature of Love-Simplified, 25 AM. Psychologist 161 (1970).

36. Even the common law managed to recognize this interest in its development of damages remedies for alienation of affections or breach of promise to marry. Today these remedies are properly in disfavor, but their decline implies no depreciation of the interests they were designed to serve. See, e.g., Brown, Breach of Promise Suits, 77 U. PA. L. REv. 474 (1929).

37. See, e.g., J. Baldwin, Another Country (1960) (novelist); J. Sartre, Being and Nothingness 474-93 (Barnes transl. 1966) (philosopher); R. LAing, The Politics of the FAMILY AND OThER Essays (1969) (psychiatrist). In his 1967 Reith Lectures, Edmund

Leach captured this view in a few words:

The [modern] family looks inward upon itself; there is an intensification of emotional stress between husband and wife, and parents and children. The strain is greater than most of us can bear. Far from being the basis of the good society, the family, with its narrow privacy and tawdry secrets, is the source of all our discontents.

E. Leach, A Runaway WORLD? 44 (1968).

38. See, e.g., R. Weiss, Marital Separation 279 (1975); Norton \& Glick, Frequency, Duration, and Probability of Marriage and Divorce, 33 J. Marriage \& FAMILY 307 (1971).

39. The qualification "normally" is necessary to take account of those cases in which the caring may not be reciprocal, as in the case of a parent's caring for a newborn infant.

40. See generally M. MaYeroff, ON Caring (1971).

41. Leonard Boonin speaks of this kind of commitment as a "covenant" in which persons become "internally related." Boonin, Man and Society: An Examination of Three Models, in Nomos XI, Voluntary Associations 69, 78 (R. Pennock \& J. Chapman eds. 1969) [hereinafter cited as Voluntary Associations]. 
one's interests in a particular intimate association. First, while it is undoubtedly possible to have a sense of commitment to an association one has not chosen ${ }^{42}$ surely that sense is heightened when there is a measure of real choice whether to maintain the association. When this choice is exercised, the cared-for partner gains in self-respect by seeing himself through his caring partner's eyes as one who is worth being cared for; the caring partner affirms her autonomy and her responsibility by choosing the commitment. ${ }^{43}$

Second, while commitment means an expectation of constancy over a period of time, any effective legal shelter for this value must offer some protection to casual associations as well as lasting ones. Suppose John and Mary become sexually intimate. Will their encounter amount to nothing more than one of those "surface relationships" and "quick exchanges" 44 that are an American disease, or will it be the beginning of an intimate association that endures? One reason for extending constitutional protection to casual intimate associations is that they may ripen into durable intimate associations. Indeed, the value of commitment is fully realizable only in an atmosphere of freedom to choose whether a particular association will be fleeting or enduring. A doctrinal system extending the freedom of intimate association only to cases of enduring commitment would require intolerable inquiries into subjects that should be kept private, including states of mind. 45

\section{Intimacy}

Much of the impressive literature generated by the Griswold opinion has delved and raked the soil of definition; yet even today there is disagreement over the meaning of privacy. ${ }^{46}$ Part of the reason for

42. The small child's commitment to his family is an example. Others are to be found in earlier times, or in societies offering little mobility: the member of the clan, or the congregation, may be loyal and committed without ever having given a moment's thought to questions of associational choice.

43. See M. Mayeroff, supra note 40, at 59; cf. H. Lynd, On Shame and the Search FOR IDENTITY 237 n. (1958).

44. D. Bell, The Cultural Contradictions of Capitalism 118 n. (1976). See generally J. Dewey, Individualism Old and New 54-55 (1929).

45. There is irony here, because casual sexual intimacy usually is the exact antithesis of the intimacy that involves caring. Yet if the freedom of intimate association is to extend to lasting nonmarital relationships, the practical argument for protecting casual association becomes conclusive.

46. See, e.g., C. Fried, AN ANatomy of Values 137-52 (1970); Freund, Privacy: One Concept or Many, in PrIvacy, supra note 13, at 182; Gavison, Privacy and the Limits of Law, 89 Yale L.J. 421 (1980); Gerety, Redefining Privacy, 12 Harv. C.R.-C.L. L. REv. 233 (1977); Rachels, Why Privacy is Important, 4 Philosophy \& PuB. Afr. 323 (1975); Reiman, Privacy, Intimacy, and Personhood, 6 Philosophy \& PUB. AFr. 26 (1976); Scanlon, Thomson 
this definitional discord is that while most of the writers link the notions of privacy and intimacy, they do not explicitly acknowledge that the term "intimacy" embraces two concepts.

The first meaning of intimacy is synonymous with one of the meanings of privacy: ${ }^{47}$ an intimate fact is a private fact, the sort of information about a person that is not normally disclosed widely, but is kept secret from all but a few. ${ }^{48}$ Intimacy has a different meaning, however, when it refers to a type of close and enduring association between people. Thus we may speak of intimate friends, or of lovers who share an intimate relationship. ${ }^{49}$ It is this second variety of intimacy that is one of the central values of intimate association. Yet intimacy in the sense of informational privacy is, as Charles Fried has shown, a necessary foundation for intimacy in the sense of love or friendship. ${ }^{.00}$ Justice Douglas's Griswold opinion blends references to both sorts of intimacy; he seeks to defend the marital bedroom against hypothetical prying officials and to defend the intimacy of the marriage relationship. ${ }^{51}$ More generally, the privacy of the home is constitutionally protected not only because the home is seen as a sanctuary, privileged against prying eyes, ${ }^{52}$ but also because it is the place where most intimate associations are centered.

Caring for an intimate requires taking the trouble to know him ${ }^{53}$ and deal with him as a whole person, not just as the occupant of a role. $^{54}$ This fact alone limits the number of intimate associations any

on Privacy, 4 Philosophy \& Pub. AFF. 315 (1975); Thomson, The Right to Privacy, 4 Philosophy \& Pub. AfF. 295 (1975); Comment, A Taxonomy of Privacy: Repose, Sancluary, and Intimate Decision, 64 CALIF. L. REv. 1447 (1976).

47. Alan Westin's definition is generally accepted as a useful definition of privacy: "Privacy is the claim of individuals, groups, or institutions to determine for themselves when, how, and to what extent information about them is communicated to others." A. Westin, Privacy and Freedom 7 (1967). Some say his definition is incomplete, however. See, e.g., Gavison, supra note 46, at 426-28; Gerety, supra note 46, at 281-95.

48. In this sense of the word, personal information disclosed only to a counselor or doctor may be intimate facts; similarly, even a casual sexual relationship involves intimacy in the sense of selective disclosures of intimate information.

49. Jeffrey Reiman speaks of intimacy in this sense when he says that the crucial feature of intimacy is "the context of caring which makes the sharing of personal information significant," and identifies a prime ingredient of that caring as "a reciprocal desire to share present and future intense and important experiences ...." Reiman, supra note 46 , at 33 .

50. C. FrIEd, supra note 46 , at $75-86,137-52$.

51. Griswold v. Connecticut, 381 U.S. 479,485 (1965).

52. See Comment, supra note 46, at 1456-65; cf. Stanley v. Georgia, 394 U.S. 557, 56466 (1969) (Constitution protects right to possess pornography in privacy of one's home against governmental intrusions).

53. See M. MAYEROFF, supra note 40 , at 13 .

54. See R. UNGER, supra note 13 , at 262. 
one person can have at any one time, or even in a lifetime.55 Professor Fried's main point in his early writings on privacy was that love and friendship are founded on intimacy's economy of scarcity, ${ }^{56}$ and this aspect of his argument seems to me to have weathered not only its chief published criticisms ${ }^{57}$ but his own recent confession of error. ${ }^{58}$ The point is significant in the context of constitutional protection of the freedom of intimate association. Given the limited number of occasions for invoking the value of intimacy, there is at least a partial response to the rhetorical question about stoppingplaces that is typically fired at an emerging doctrinal formulation. ${ }^{59}$

In any case, the core associational value of intimacy is not to be reduced to its instrumental uses. It is valued for itself, for the emotions it generates immediately, and not merely for "the emotional attachments that derive from the intimacy of daily association." a marriage, or a family, or another comparable association is a "haven in a heartless world," 61 the emotional shelter it provides is founded on intimacy.

\section{Self-identification}

Whether one's intimate associations be affirming or destructive or both, they have a great deal to do with the formation and shaping of an individual's sense of his own identity. ${ }^{62}$ It is an individual's intimate associations that give him his best chance to be seen (and thus to see himself) as a whole person rather than as an aggregate

55. Id. at 219; M. MAYerofF, supra note 40, at 38 . There are only so many people with whom one can share experiences that are "intense and important." Reiman, supra note 46 , at 33 .

56. Fried, Privacy, 77 YAle L.J. 475, 484-85 (1968).

57. E.g., Reiman, supra note 46, at 31-33; Posner, The Right of Privacy, 12 GA. L. REv. 393, 407-09 (1978). The case for decriminalizing prostitution thus rests not so much on intimate associational values as on more general claims, such as a right of sexual autonomy or a woman's right to self-determination. David Richards argues that case in an article that manages to be both sensitive and forceful. Richards, Commercial Sex and the Rights of the Person: A Moral Argument for the Decriminalization of Prostitution, 127 U. PA. L. REv. 1195 (1979).

58. Fried, Privacy: Economics and Ethics: A Comment on Posner, 12 GA. L. Rev. 423, 426-27 (1978).

59. See, e.g., Douglas v. California, 372 U.S. 353, 362 (1963) (Harlan, J., dissenting).

60. Smith v. Organization of Foster Families for Equality and Reform, 431 U.S. 816, 814 (1977).

61. C. Lasch, Haven in a Heartless Wortd (1977).

62. See, e.g., H. Gerth \& C. Mills, Character and Social Structure 11, 84-86, 90-91 (1953). The term "identity," I concede, is overworked and underdefined. See generally W. Mackenzie, Polimical Identity (1978). I use it here to refer both to one's sense of being an individual and to one's sense of identification with others. Both are part of what it means to be a person, to have a sense of self. C. FRIED, supra note 46, at 75.86; R. UNGER, supra note 13 , at 193. 
of social roles. ${ }^{63}$ For most of us, our intimate associations are powerful influences over the development of our personalities. ${ }^{64}$ Our relations with "significant others" 65 may add up to a "paradox of sociability," "bo but in the formation of our senses of self they are the only game in town: "Some kind of answer to the question Where do I belong? is necessary for an answer to the question Who am I?" 07

An intimate association may influence a person's self-definition not only by what it says to him but also by what it says (or what he thinks it says) to others. ${ }^{88}$ In the traditional domain of the freedom of association, this phenomenon of association-as-statement is familiar. In the politics of the $1960 \mathrm{~s}$, political association served not only to promote specific policy goals but also as an outlet for expressiveness, for self-identifying assertions. So it is with many intimate associations. Indeed, as the legal consequences of a couple's living together come to approximate those of marriage, and as divorce becomes more readily available, marriage itself takes on a special significance for its expressive content as a statement that the couple wish to identify with each other. ${ }^{69}$ Similarly, the decision whether to have a child is a major

63. R. UNGER, supra note 13, at 262-63.

64. For example, a child's mental picture of the "family" may be a "dramatic template," a more or less permanent, internalized structure of human relations around which her perceptions of others and her actions toward them may be organized long after childhood's end. R. LAING, supra note 37 , at 17 .

The Editors of the Journal disagree with my use of alternating masculine and feminine pronouns to refer to individuals in the abstract, but they have kindly allowed me to follow my preference in the matter. If anyone cares, I have sketched the reasons for that preference in a short article. Karst, "A Discrimination So Trivial": $A$ Note on Law and the Symbolism of Women's Dependency, 35 OHг ST. L.J. 546 (1974).

65. H. Gerth \& C. Mills, supra note 62 , at 86.

66. R. UNGER, supra note 13 , at 217.

67. H. LYND, supra note 43, at 210 . For a law-oriented discussion of the self as a series of roles, see J. ViNing, Legal IDENTITY 59, 146-47, 152-53 (1978).

68. See E. Goffman, Stigma: Notes on the Management of Spoiled Identity 105.06 (1963) (distinguishing "ego identity" and "social identity").

69. See E. Goffman, The Presentation of the Self in Everyday Life 77-105 (1959) (on presentation of self as member of a "team"); cf. L. TribE, supra note 19, at 887.88 (privacy values are matched by outward-looking aspects of the self, including right to make "statement" implicit in public identity). Getting married may also be an implicit statement of devotion to the institution of traditional marriage, or a symbol of one's intention to procreate. See Weitzman, Legal Regulation of Marriage: Tradition and Change, 62 CALIF. L. REv. 1169, 1211-16 (1974) ("pronatalist" assumptions of traditional marriage contract).

Similarly, a proceeding to determine paternity may be brought by the child's putative father, and resisted by the mother, for reasons centered on the status itself (as opposed to any material rights or obligations associated with the status). See, e.g., Johannesen v. Pfeiffer, 387 A.2d 1113 (Me. Sup. Jud. Ct. 1978); Perez v. Stevens, 362 So. 2d 998 (Fla. 1978), cert. denied, 100 s. Ct. 72 (1979). The father in such an action typically seeks visitation rights as well as a declaration as to his status. 
occasion for self-definition. ${ }^{70}$ To become a father or mother is to assume a new status, a new identity in the eyes of oneself and others.

Transient or enduring, chosen or not, our intimate associations profoundly affect our personalities and our senses of self. When they are chosen, they take on expressive dimensions as statements defining ourselves.

\section{B. Freedom and the Values of Intimate Association}

It is the choice to form and maintain an intimate association that permits full realization of the associational values we cherish most. The connection between the choice principle and these values is delicate but vital. It is possible, of course, to realize some measure of the values of self-identification, intimacy, and caring and commitment through an intimate association one has not chosen. ${ }^{71}$ In general, however, freedom of associational choice enhances the values of intimate association to a degree that would not be attainable if choice were absent. A chosen intimate association can serve, for example, as a statement of self-identification in a way that cannot be matched by an association imposed by force of law, and intimacy implies the choice not to associate oneself in intimate ways with the world at large.

The full value of long-term commitment is also realizable only when there is freedom to remain uncommitted. Not only is the freedom to reject or terminate an intimate association valuable in its own right; it also promotes the realization of values in an intimate association that endures. The way to confront "the paradox that making divorce fundamental, and thus readily obtainable, might in the end make marriage seem much less so" 72 is to expose the paradox's implicit premise. The paradox arises only if we identify a spouse's commitment with the act of marrying. That act undoubtedly carries greater weight as an announcement of commitment when the wife binds herself to a marriage from which exit will be difficult. But from the wedding day forward, there is a progressive decline in that act's significance for the associational value of commitment. What begins to matter more for the husband is not that his wife was once ready to bind herself to him by ties enforceable by the state, but that she remains

70. Many pregnancies, and their ensuing childbirths, are unchosen; I am speaking of the case in which there is, in fact, a decision to have a child.

71. In a society offering no genuine associational options, an arranged marriage may turn out to have been made in Heaven. Even in our own society, a young child ordinarily will identify with his family, care for them, and feel committed to them despite the fact that he exercised no choice in forming the association.

72. Wilkinson \& White, supra note 15 , at 577 . 
committed to him, day by day-not because the law commands it but because she chooses the commitment. As the "paradox" quotation suggests, easing exit from marriage may reduce the import of the act of marriage as an initial statement. But once the act of marriage recedes into the past, the freedom to leave gives added meaning to the decision to stay. ${ }^{73}$

The freedom of nonassociation, it is often noted, is itself an associational freedom. ${ }^{74}$ The validity of this proposition is not limited to cases of intimate association; it is, for example, equally applicable to associations that are primarily ideological..$^{55}$ As rape and unwanted pregnancy dramatically illustrate, however, coerced intimate associations are the most repugnant of all forms of compulsory association.70 The two strongest cases for protecting the freedom of intimate association, then, are the case of "consenting adults" who choose to associate with each other, and the case of the unwilling person who is compelled to maintain an unwanted association with another. ${ }^{77}$

There is truth as well as felicity in Professor Tribe's comment that "virtually every intrusion upon association works a displacement of human personality." " But some of those intrusions plainly do more displacing than others do. There is some intrusion, for example, on the freedom of nonassociation when Congress forbids a private secondary school to exclude black applicants. Yet, as Justice Powell argued, ${ }^{79}$ the associational freedom claim here is weaker than an analogous claim in a case involving intimate association. Moreover, if one looks to the values at stake, it is easy to see that the case is not a sim-

73. A problem of a different order of magnitude lurks in this discussion. Mutual commitment means that both spouses internalize not only their devotion to each other, but their sense of identification with each other. Should the wife, then, be able simply to walk away from her expressed commitment to her husband? The freedom of intimate association speaks to such questions not by offering answers, but by identifying them as questions of moral rather than legal obligation.

74. E.g., L. TRIBE, supra note 19, at 974 .

75. See Comment, The Right of Ideological Nonassociation, 66 Calif. L. REv. 767 (1978).

76. See Runyon v. McCrary, 427 U.S. 160, 187-88 (1976) (Powell, J., concurring). Some such notion, founded on the intimacy of the family relationship or the privacy of the home, surely was in Justice Powell's mind when he remarked that a "personal" contract forming the basis for a "close association (such as, for example, that between an employer and a private tutor, babysitter, or housekeeper)" would "invoke associational rights long respected," even in the face of a congressional prohibition against racial discrimination in contracting.

77. In multisided cases, or cases involving children who are too young to "choose," the principle of free choice may be insufficient to illuminate even the claim of freedom of association, let alone the justifications for its impairment. Absent such qualifying factors, however, that claim is a powerful one.

78. L. TRIse, supra note 19 , at 974 .

79. Runyon v. McCrary, 427 U.S. 160, 186.89 (1976) (concurring opinion). 
ple stand-off between two competing claims to associational freedom. ${ }^{80}$ If the white student who now must share the school with black students has any sense of self on the line at all, it is a self that profits from a claim to racial superiority and advantage. In contrast, the black who seeks admission to the school is making a self-identifying statement that he is fit as a person, and entitled as a citizen, to associate with others in such a public place. The school's denial of that fitness and entitlement is a "displacement of human personality" in the highest degree.

The force of the principle of associational choice thus varies in proportion to the magnitude of threatened invasions of the values of intimate association. It remains for us to explore the implications of the choice principle as it bears on husband-wife relations, the decision whether to procreate, and the relations of parents and their children.

Our law has long maintained a "hands-off" attitude toward interspousal disputes. ${ }^{81} \mathrm{~A}$ marriage is an association emphasizing "shared commitment" rather than rules. ${ }^{82}$ It is a relationship in which the spouses deal with each other on so many levels, both practical and emotional, that their relations are necessarily diffuse rather than particularized, "exploratory and creative" 83 rather than fixed. The resolution of differences between spouses who intend to stay together looks toward healing the relationship for the future, not settling up old transgressions.

The law has traditionally disfavored contracts between spouses. ${ }^{84}$

80. The "stand-off" notion was Professor Wechsler's suggestion. Wechsler, supra note 4 , at 34 .

81. See Glendon, Power and Authority in the Family: New Legal Patterns as Reflections of Changing Ideologies, 23 AM. J. CoMp. L. I (1975). For the view that "family autonomy" in the husband/wife context largely leaves wives in a subordinate position, see Powers, Sex Segregation and the Ambivalent Directions of Sex Discrimination Law, 1979 Wis. L. REv. 55; Weitzman, supra note 69.

82. See Fuller, Two Principles of Human Association, in Voluntary Associations, supra note 41 , at 3, 6. So long as the marital union lasts, "our law has not in general undertaken to resolve the many delicate questions inherent in the marriage relationship. ... Some things must be left to private agreement." Doe v. Doe, 365 Mass. 556, 563, 314 N.E.2d 128, 132 (1974).

83. Benn, supra note 13, at 17. For the classic exposition of the diffuse obligations in such a "multiplex" relationship, see M. Gluckman, The Judicial Process Among the BAROtSE OF NORTHERN RHOdesia 20-24 (1955).

84. This tradition no doubt supported a system of patriarchy now rightly discredited. See Weitzman, supra note 69, at 1170. See generally Hunter, An Essay on Contract and Status: Race, Marriage, and the Meretricious Spouse, 64 VA. L. REv. 1039 (1978); Note, Marriage as Contract: Towards a Functional Redefinition of the Marital Status, 9 Colum. J.L. \& Soc. Pró. 607 (1973). I am not suggesting that all interspousal contracts, or what are known today in California as "Marvin agreements" between unmarried couples living together, so named in honor of the much-publicized case of Marvin v. Marvin, 18 Cal. 3d 660, 557 P.2d 106, 134 Cal. Rptr. 815 (1976), should be disregarded by the courts. 
When such a contract goes beyond post-dissolution obligations to specify such expectations as "personal goals within the relationship," "responsibility for household tasks," "clarification of each partner's religious commitment," or "ground rules for arguments," 85 it is easy to see that the old law had its points. The parties to such a contract will not even be aware of all the different ways in which they will interact, let alone how those interactions will change during an unpredictable future. Furthermore, if an intimate association is to nourish the sense of individuality, its members must be able to see each other whole, ${ }^{86}$ not as a net balance of contractual performances and defaults. There are sound reasons for the state to leave the members of an ongoing intimate association alone, to let them carry on their relations with a minimum of state intervention. ${ }^{87}$ If they cannot work out their differences, the exits are clearly marked.

The decision whether to procreate is also an exercise of associational choice. One chooses to be a parent, given today's facility of contraception and abortion, much as one chooses to marry. ${ }^{88}$ The decision to have a child, whether within or outside marriage, strongly implicates the values of intimate association, particularly the values of caring and commitment, intimacy, and self-identification. The decision ranks in importance with any other a person may make in a lifetime; an attempt to imagine state interests that would justify governmental intrusions amounting to a practical prohibition on procreation and childbearing takes us out of our own experience and into an imaginary world of Malthusian nightmare. ${ }^{80}$

Because the decision to procreate implicates so intensely the values of intimate association, significant state interference with the choice not to procreate also requires justification by reference to state interests of the highest order. Griswold and its successor decisions defend

No associational freedom interest is violated by judicial enforcement of a contract specifying the disposition of property or the allocation of support obligations on termination of a marriage or other intimate association.

85. See Weitzman, supra note 69 , at $1250-53$ (suggesting contract topics).

86. R. UNGER, supra note 13 , at 262; Fuller, supra note 82 , at 17.

87. See Wellington, Common Law Rules and Constitutional Double Standards: Some Notes on Adjudication, 83 YALE L.J. 221, 292 (1973).

88. Justice Douglas was on sound ground when he connected the two kinds of decision in his opinion in Skinner v. Oklahoma, 316 U.S. 535 (1942). An unmarried couple who have been living together recognize this associational parallel when they say they have decided to marry because they "want to have a family." Children are valued not only for themselves, but as living expressions of their parents' love for each other. See Blustein, Child Rearing and Family Interests, in Having ChILdREN 115, 118 (O. O'Neill \& W. Ruddick eds. 1979).

89. See Note, Legal Analysis and Population Control: The Problem of Coercion, 84 Harv. L. Rev. 1856, 1865-69 (1971); cf. G. Calabresi \& P. BobbitT, Tragic Choices (1978). 
not only the values of intimate association but also the values of nonassociation, protecting men and women-but particularly women -against the enforced intimate society of unwanted children, against an unchosen commitment and a caring stained by reluctance, against a compelled identification with the social role of parent. Coerced intimate association in the shape of forced childbearing ${ }^{00}$ or parenthood is no less serious an invasion of the sense of self than is forced marriage or forced sexual intimacy. ${ }^{\text {11 }}$

Additionally, Griswold and its successors not only protect the individual who chooses not to procreate, but also the autonomy of a couple's association, whether it be a marriage or an association of unmarried intimates. The Griswold opinion makes this point explicit, in the context of marriage, in the passage quoted at the beginning of this Article. The Court's opinion in Eisenstadt v. Baird ${ }^{92}$ effectively gives unmarried couples the same power to govern the intimacies of their association. If, in the minds of an unmarried couple living together, marriage implies a new commitment, and marriage and childrearing are linked, it is of great importance to be able to defer procreation until they are sure they want to make the commitment implicit in marrying. To reduce the matter to a cooler syllogism, if there is a constitutional right to live together in intimacy without marrying, then Eisenstadt follows deductively from Griswold..$^{93}$

None of the foregoing argument leads to the conclusion that the

90. Given our society's prevailing assumptions about allocating the responsibility for child-rearing, there is, as Grace Blumberg remarked in a conversation with me, unintended truth in Professor Ely's disparaging comment about abortion as a "super-protected right." Ely, The Wages of Crying Wolf: A Comment on Roe v. Wade, 82 Yale L.J. 920, 935 (1973). The implications of an unwanted child for a woman's education, employment opportunities, and associational opportunities (often including marriage opportunities) are of enormous proportion. "Birth control is woman's problem." $M$. SANGER, Woman and THE New RACE 100 (1920). An alternative to abortion, of course, is placement of the child for adoption. By the time the child is born, however, there is an intimate association between mother and child, founded in part on the mother's sense of responsibility for the fetus during pregnancy, and consequently a strong pull on the mother toward keeping the child. See L. TRIBE, supra note 19, at 924 \& n.19.

91. When a woman's choice to have an abortion is opposed by the would-be father, the case is not a simple stand-off of associational values, any more than is the case in which $A$ wishes to marry $B$, but $B$ is unwilling. The Supreme Court was correct in holding invalid a law that gave a husband a veto over his wife's intended abortion. Planned Parenthood of Mo. v. Danforth, 428 U.S. 52 (1976). A federal district court recently held invalid a Florida statute requiring a married woman to notify her husband and consult with him when she intends to have an abortion, holding that the law unconstitutionally burdened the right to terminate a pregnancy during the first trimester. Scheinberg v. Smith, 48 U.S.L.W. 2458 (S.D. Fla. 1979).

92. 405 U.S. 438 (1972).

93. The Griswold principle surely applies to enduring intimate relationships; this extension to persons involved in more casual relationships follows for reasons already suggested. See p. 633 supra. 
state is forbidden absolutely to impose any burden on the decision whether to procreate, or even that every such burden must be justified by some heroic showing of governmental necessity. Such a high standard of justification unquestionably is required when the state flatly denies the right to procreate or the right to refrain from procreating. But some burdens on those decisions will be of lesser significance, requiring lesser justification..$^{94}$

Complications multiply when we move from the intimate association of adults to the relations between parents and children. Autonomy, surely, is one of the chief hopes we have for our children, and yet all would agree that the hope for autonomy is realized piecemeal. The capacity to tie one's own shoelaces is one thing, and the capacity to choose to have an abortion is another-and the word "capacity" has two different meanings here. ${ }^{95}$ Part of the normal process of a child's development is the guidance she receives from her parents. The question is when that guidance should be backed up by the state's coercive power.

The Supreme Court, in its most recent pronouncement on the subject, spoke warmly of "the family as a unit" that thrives in the context of parental control over children, despite its poor health in the context of husbands' control over wives. At the same time, the Court has recognized the tension between this perception of the family as community and the atomizing ideals of liberty, ${ }^{97}$ which seem to call for due process protections of children against some of their parents' decisions. ${ }^{98}$ Still, in parent-child rela-

94. Suppose, for example, that a school board were to insist that a pregnant teacher take three weeks of maternity leave before the expected delivery of her child. Such a rule would no doubt pass constitutional muster, and no one would be heard to complain about "irrebuttable presumptions." Cf. Cleveland Bd. of Educ. v. LaFleur, 414 U.S. 632, 648 (1974) (school boards may not conclusively presume that all pregnant women are unfit to teach past fourth or fifth months of pregnancy). Similariy, the constitutional flaw in Dandridge v. Williams, 397 U.S. 471 (1970), does not lie in any failure to protect the freedom of intimate association.

95. For an analysis carefully separating the questions to be asked in various factual contexts for claims of rights of children, sec Wald, Children's Rights: A Framework for Analysis, 12 U.C. Davis L. REv. 255 (1979).

96. Parham v. J.R., 99 S. Ct. 2493, 2504 (1979). Robert Burt has shown how the Court's seeming solicitude for family autonomy in this and other recent decisions is more usefully seen as deference to "state-employed behavioral professionals." Burt, The Constitution of the Family, 1979 Sup. Cr. REv. 329, 334. See generally Burt, Developing Constitutional Rights of, in, and for Children, 39 LAW \& ConteMp. Prob. 118 (Summer 1975).

97. This tension has been noted by sociologists, e.g., C. LAsch, THE Culture of Narcissism 154-86 (1978); Goode, Force and Violence in the Family, 33 J. Marriage \& FamiLY 624 (1971), and lawyers alike, e.g., L. TRIBE, supra note 19, at 898. For the view that courts should be more ready to intervene in family affairs for the purpose of provoking healthy confrontation of alienated family members, see Burt, supra note 96, at 358-71.

98. The occasion for this recognition was the holding that due process does not entitle a child to an adversary hearing before commitment by his parents to a mental hospital. 
tions, hierarchy remains the law's central principle. ${ }^{90}$ The freedom of intimate association counsels severe restrictions on the state's power to intervene, either to enforce parental authority or to weaken it.

The child born into a family exercises no choice about the ensuing association. After the child has reached some level of maturity, however, it becomes sensible to speak of the continuing family relationship as a matter of choice. ${ }^{100}$ Within the family that stays together, parent-child relations are, from some point in the child's teenage years forward, a matter of intra-family agreement. Even when parental discipline is the rule, it rests on the child's consent, once the child is capable of making an independent life for himself.

These assertions are founded on the same considerations of intrafamily associational choice and harmony that require the state to keep its hands off the husband-wife relationship. The point is not that family life prospers best when parents negotiate with their children rather than give them orders. It is that invoking the power of the state to bring children to heel is destructive of the values of caring and commitment, intimacy, and self-identification. Let it be conceded that most children want and need parental discipline. A constitutional presumption against using police officers and juvenile halls to enforce that discipline is not inconsistent with that assumption.

Because the state primarily supports parental discipline by leaving its establishment and maintenance to intra-family choice, ${ }^{101}$ both chil-

Parham v. J.R., 99 S. Ct. 2493, 2507-08 (1979).

The law's concept of the family rests on a presumption that parents possess what a child lacks in maturity, experience, and capacity for judgment required for making life's difficult decisions. More important, historically it has recognized that natural bonds of affection lead parents to act in the best interests of their children.

Id. at 2504 .

99. Parental rights can be terminated for incapacity, or for serious neglect. The state can also override particular parental choices that are grossly inappropriate, such as the refusal to seek medical attention for a child. See generally Goldstein, Medical Care for the Child at Risk: On State Supervention of Parental Autonomy, 86 YALE L.J. 645 (1977); Mnookin, Child-Custody Adjudication: Judicial Functions in the Face of Indeterminacy, 39 Law \& ConteMp. ProB. 226 (Summer 1975) (discussing termination of parental rights).

100. In cases involving foster parents, adoptions, or custody contests, it is by no means unusual for a court to defer to the associational preferences of a child. Even in the ordinary nuclear family, it may be possible as a practical matter for an older child to leave the household and make his own way, free from the parental control authorized by law, in the anonymity offered by urban society. In some cases, the child need not try to disappear, but can be emancipated by judicial decree. For a discussion of recent California legislation on the subject, see Note, The Emancipation of Minors Act: A California Solution for the Mature Minor, 12 U.C. DAvis L. Rev. 283 (1979).

101. See Bellotti v. Baird, 99 S. Ct. 3035 (1979); same case, 428 U.S. 132 (1976); Planned Parenthood of Mo. v. Danforth, 428 U.S. 52 (1976). In Danforth, the Court held that the state could not constitutionally give a pregnant minor's parents an absolute veto over her decision to have an abortion. No doubt the Court recognized that most pregnant minors would be well into teen age, and that when such a girl chooses to have 
dren and parents have the opportunity to make the commitment implicit in maintaining the family unit. ${ }^{102}$ That commitment, in turn, contributes to satisfying the need of children to identify themselves by identifying with their parents. Anthropologists speak of kinship by consanguinity or affinity; ${ }^{103}$ there is a sense in which all kinship, after some critical stage of child development, becomes kinship by affinity. The values of intimate association increasingly come to depend on the child's willingness to identify with his parents and to be committed to maintaining a caring intimacy with them. ${ }^{104}$ The freedom of intimate association should protect even this right to "choose" one's parents, once that critical stage has been reached.105

Before that time, however, there is wisdom in leaving a wide range of control over children to their parents. Such a course is generally consistent with the principle of free choice, as centuries of legal assumptions about child incapacity attest. For young children, a presumption in favor of parental control not only accords with legal

an abortion, her parents usually will not seek to prevent her from carrying through that decision. The cases that remain are the unusual ones, when a very young girl becomes pregnant or when the girl and her parents are unable to reconcile their difference over the question of an abortion. The Court reserved the first case for another day, id. at 75, and still has not given us a definitive resolution for it. See Bellotti v. Baird, $99 \mathrm{~S}$. Ct. 3035 (1979). As for the second case, the Court expressed doubt that providing the parents with a veto over their daughter's abortion decision would "strengthen the family unit" or "enhance parental authority or control where the minor and the nonconsenting parent are so fundamentally in conflict and the very existence of the pregnancy already has fractured the family structure." 428 U.S. at 75.

Whether or not a pregnancy alone would have the fragmenting effect the Court suggested, its other argument was soundly based in the freedom of intimate association. The daughter's decision whether to have a child is an associational choice of the first importance; moreover, her relations with her parents, including her acceptance of their discipline, are themselves presumptively beyond the state's reach.

102. A minuscule proportion of parent-child disputes reach the point where use of the state's power is even considered by the parents, let alone invoked. Even the recent decisions on the question of a parental veto over a minor child's decision to have an abortion arose out of class actions supported by institutional litigants to challenge Iaws in the abstract. Bellotti v. Baird, 99 S. Ct. 3035 (1979); same case, 428 U.S. 132 (1976); Planned Parenthood of Mo. v. Danforth, 428 U.S. 52 (1976).

103. E.g., R. Beals, An Introduction to Anthropology 513 (3d ed. 1965); Reichard, Social Life, in General Anthropology 409, 450-58 (F. Boas ed. 1938).

104. Children can recognize parental discipline as something that grows out of love. The parents understand that the discipline they impose is always an exercise in persuasion; this realization provides important support for the associational value of caring by influencing the parents' disciplinary decisions in directions that permit the children to see their basis in parental love.

105. The assertion in the text does not speak to the concerns that may justify limitations on this freedom. The point is that the freedom does require a search for justifications.

On the consequences of enforced prolongation of child dependency, see Marks, Detours on the Road to Maturity: A View of the Legal Conception of Growing Up and Letting Go, 39 Law \& Contemp. Prob. 78 (Summer 1975). 
tradition and common sense but is dictated by notions of family autonomy. ${ }^{100}$ This much of the Supreme Court's opinion in the civil commitment case of Parham v. J.R. ${ }^{107}$ seems indisputable, and it is not surprising that the Court was unanimous on the point. ${ }^{108}$

So long as a marriage is intact, the law will no more interfere in interspousal disputes over child-rearing than it will in other husbandwife controversies. ${ }^{109}$ Even when the marriage ends, if the parting parents agree on a custody arrangement, their choice will usually prevail. ${ }^{110}$ Further complexity appears when questions of parent-child relations become three-sided. The custody battle between separating spouses is problematic precisely because our notions of the values of intimate association are engaged on both sides of the contest. Even here, however, effective decisionmaking can be promoted by a particularized inquiry into the way those values come to bear on the case at hand.111 Typically, and properly, such cases are decided not on

106. See Mnookin, supra note 99 , at $230-46$.

107. 99 S. Ct. 2493 (1979).

108. The Court was not unanimous on all issues in the case. Justice Brennan agreed that preconfinement hearings would not be necessary in all cases in which parents sought to commit their children, but thought that the Court should hold that at least one post-admission hearing was required by due process. Id. at 2516 (Brennan, J., concurring).

109. See p. 639 supra.

110. But see Bergstrom v. Bergstrom, 478 F. Supp. 434 (D.N.D. 1979) (eight-year-old girl can choose, despite her divorcing parents' agreement to contrary, to remain in United States rather than return with her mother to Norway).

111. See, e.g., J. Goldstein, A. Freud, \& A. Solnit, Beyond the Best Interests of the Child (1973) [hereinafter cited as Best INTEREsTs]. In the past, the law has either flatly disqualified certain persons from child custody or erected presumptions against their having custody. Some of these disqualifications and presumptions are on the way to legislative repeal or judicial abandonment in several jurisdictions. Thus the presumption that the mother should have custody of a small child has been eliminated by statute in a number of states. Comment, Joint Custody: An Alternative for Divorced Parents, 26 UCLA L. REv. 1084, 1092 \& $\mathrm{nn}$. 44.45 (1979). The Uniform Marriage and Divorce Act prohibits child custody adjudications based on notions of spousal fault or on questions of morality that do not affect a parent's relationship with his child. UNIFORM MARriage \& Divorce Act \$ 402 (1979). See generally Weitzman \& Dixon, Child Custody Awards: Legal Standards and Empirical Patterns for Child Custody, Support and Visitation After Divorce, 12 U.C. Davis L. REv. 471 (1979).

A number of these nonconstitutional trends in the law reflect the implications of the freedom of intimate association. Any disqualification of a parent from child custody because of the parent's unmarried cohabitation, homosexuality, or single status, is as defective in the constitutional sense as was the disqualification of the father of an illegitimate child struck down by the Supreme Court in Stanley v. Illinois, 405 U.S. 645 (1972). Some such persons may indeed be unfit parents, but that unfitness is by no means universal, and to disqualify them automatically from custody of their children intrudes not only on their association with their children, but on their other intimate associations as well. Even the denial of custody because of physical or mental incapacity should trigger the closest judicial scrutiny, to assure that the denial truly is based on an inability to fulfill the responsibilities of parenthood and not on stereotypical assumptions based on the stigma associated with those disabilities. 
the basis of specific rules of law, but by the sort of discretionary, whole-person evaluation appropriate for intimate associations. ${ }^{112}$

When a child's parents are not living together, most of the parental control over the child naturally is exercised by the parent who has custody. Inter-parent disputes about child-raising are thus chiefly resolved in proceedings aimed at transferring custody from one parent to the other. If the parents have never been married, still another complication can be presented in the form of a petition by the custodial parent's spouse to adopt the child. If the other parent resists

112. Fuller, supra note 82, at 18-19. Custody decisions in most divorce cases are routinely upheld by appellate courts, for reasons all can accept. An appellate court rarely can have the trial judge's sense of the human dimensions of such a case, and the custody decision requires that people be seen whole, not judged according to rules. Thus discretion, not rule, necessarily governs such cases. As a result, the trial judge has the opportunity to import her own prejudices into the decision with low visibility. Is the prospective custodial parent living with someone outside marriage? Does he suffer from a physical handicap? In a system dominated by trial-judge discretion, such questions may have relevance for particular judges even though they are constitutionally suspect or forbidden. The freedom of intimate association thus demands that an appellate court take a closer look at a custody decision when the losing party makes a colorable claim that he has been the victim of the judge's determination to make an impermissible factor the decisive one in awarding custody-that is, to employ an unconstitutional rule instead of looking at the whole person. Although reversals of custody decisions would undoubtedly still be rare, the fact that an appellate court demonstrates its alertness to this danger can serve a useful cautionary purpose.

The question of visitation rights also implicates the freedom of intimate association. In their deservedly famous book, Joseph Goldstein, Anna Freud, and Albert Solnit argued that visitation rights should be abolished in favor of a rule making visitation by the noncustodial parent a privilege to be dispensed by the custodial parent as he may see fit. The argument derives from the authors' persuasive discussion of the benefits of "emotional constancy" for the child of divorced parents, and the child's need to avoid conflicts of loyalty between "two psychological parents who are not in positive contact with each other." Best INTERESTs, supra note 111, at 25, 38. In dealing with visitation as well as other issues, the authors recognize that they have proposed a systematic subordination of the noncustodial parent's associational values to those of the child. They defend this choice in terms that would gladden the heart of Carolene Products enthusiasts. Legislators and judges are adults, they remind us, and adults "have deeply engrained irrational reservations about the primacy of children's needs." Id. at 106. Their decisions in favor of other adults are thus suspect.

At the risk of betraying some deeply engrained irrationality, can we not assert that it is no less a constitutional sin to treat parents as well as children as non-persons? $A$ noncustodial father who seeks the occasional society of his child has much to lose. Seeing the child regularly allows him to be a father, with all that implies for such values as caring and commitment, intimacy, and self-identification. Assuming that we know with some confidence what the typical child's developmental needs are, adults have developmental needs too. Cf. Skolnick, The Limits of Childhood: Conceptions of Child Development and Social Context, 39 LAW \& ConTemp. Prob. 38 (Summer 1975) (expressing skepticism about various assumptions concerning children's developmental needs). The freedom of intimate association implies a heavy burden of justification for a state that uses its courts to deny someone the right to be a parent to her own child, and it is far from obvious that the burden is sustained by a showing that children need stability. If an older child were to reject his parent's efforts at visitation, however, that would be another matter, because the termination of the parent's right would rest on the child's own choice. 
the petition, again both sides of the dispute can appeal to the abstraction of the freedom of intimate association. As in the case of a custody contest, however, the court's choice between the competing claims will be aided if the abstraction yields to a careful examination of the associational values as they appear in the particular case. ${ }^{113}$

\section{Associational Choice, Associational Status, and Entitlements to Material Benefits}

Hundreds of kinship studies by hundreds of doctoral candidates in anthropology remind us that the human family is a social relationship, not an entity defined in nature. Justice Stewart said as much in a recent dissent: "Parental rights do not spring full-blown from the biological connection between parent and child."114 $\mathrm{He}$ concluded that the state ought to be able to make formal associational status such as marriage or legitimacy the crucial element in defining the family for some legal purposes. Caution is suggested, however, by a Chon Day cartoon published some years ago in the New Yorker. Two women are talking, and one of them says, "No, no, it's Frank and Gloria who are married but not living together. George and Judy are living together but not married."115 Formal associational status plainly is neither a necessary nor a sufficient condition for the realization of the values of intimate association.

Modern law, for the most part, greets these incongruities between associational status and associational values with acceptance, or at

113. In Quilloin v. Walcott, 434 U.S. 246 (1978), the Supreme Court upheld the application in such a case of a law allowing adoption of an illegitimate child upon the consent of only the mother, unless the father had previously legitimated the child. In Quilloin, the father had never lived with his son, had never provided regular support, and had never sought legal custody of the child. $I d$. at 251. In these circumstances, and given the fact that the boy, at age 12, asked to be adopted and to take the name of his mother's husband, the state courts and a unanimous Supreme Court agreed that the father's consent was not constitutionally required.

The decision seems correct insofar as the Court upheld the adoption over the father's objection. Under the circumstances, the father was giving up rather less than the fullness of the parent-child relationship, and, after all, the boy's own associational choice should weigh heavily in the decision. It is not clear, however, that the Court should have upheld the state court's order terminating the father's visitation rights, at least not unless the son's choice as to that question were made equally clear. When there is a new adoptive father, the argument for "emotional constancy" admittedly takes on more force than it does when a court is considering the question of visitation rights for a noncustodial parent immediately after divorce. What is objectionable is that this issue of visitation should be decided by the flat rule that the state courts evidently applied in the Quilloin case. An individualized determination of the parties' interests seems called for in this situation, to avoid the use of the adoption proceeding (and the consequent termination of visitation rights) as just one more weapon in an ongoing struggle between ex-spouses.

114. Caban v. Mohammed, 441 U.S. 380, 397 (I979).

115. The New YoRker, Dec. 23, 1972, at 44 . 
least resignation. Our law typically lets people choose their intimate associations without direct interference. Even laws prohibiting homosexual conduct are rarely enforced against private consensual behavior. ${ }^{116}$ Instead, the law's interference with associational freedom typically takes the form of a rule conditioning some material benefit such as employment, inheritance, welfare payments, or Social Security on the candidate's associations in fact or formal associational status.

Virtually all enduring intimate associations raise justifiable expectations of mutual material support: spouses or "spousal equivalents" support each other; parents support minor children; when it is necessary, adult children support aging parents. The moral obligations to provide material support may be perceived to arise from individuals' occupancy of these roles, or, alternatively, simply from "the ways in which they join their lives as the individuals they are," 117 but one way or another an intimate association is normally seen to generate moral duties of a material kind, whether or not those duties are also enforceable by law.

In the cases of parents and spouses, of course, the law has long defined and enforced a number of duties of material support, along with a range of rights and obligations relating to property. It is not too much to say that the importance of family law in Anglo-American legal history arose out of the relation of associational status (marriage, legitimate parentage) to the control of property, and particularly land. The earliest association-conditioned entitlements, then, were rights of inheritance, dower, and the like, and they strongly emphasized formal legal status as the relevant conditions. ${ }^{118}$

Today, both marriage and the legitimacy of parentage have declined in importance as determinants of material benefits. Mary Ann Glendon has written of the "dejuridification" of marriage, ${ }^{119}$ and even its "withering away." 120 Her point is not that marriage is about to pass from the scene, but that there is a discernible trend in the United States and Western Europe toward withdrawal by the state from much that it has done to regulate marriage. One reason for this regulatory ebb tide surely is the rise of various forms of public and quasi-public

116. See, e.g., Project, The Consenting Adult Homosexual and the Law: An Empirical Study of Enforcement and Administration in Los Angeles County, 13 UCLA L. REv. 643 (1966).

117. A. Melden, Rights and Persons 79 (1977).

118. See generally 2 F. Pollock \& F. Maitland, The History of English Law 364-447 (S. Milsom ed., 2d ed. 1968) (family law).

119. M. Glendon, State, Law and Family 126-28, 320-23 (1977).

120. Glendon, Marriage and the State: The Withering Away of Marriage, 62 VA. L. REv. 663 (1976). 
wealth. ${ }^{121}$ The law of marriage and of legitimacy may or may not be relevant to one's entitlement to government support. No wonder the state has become less concerned with determining who can marry or who can terminate a marriage. No wonder the legal consequences of marriage are becoming harder to distinguish from those of other comparable intimate associations that do not rest on that status. ${ }^{122}$

The typical case raising issues of the freedom of intimate association today involves a claim to some material benefit, often of a nontraditional sort. In a variety of ways, entitlements are conditioned on certain forms of intimate associational status, which may or may not be the traditional forms. Correspondingly, other entitlements are conditioned on the claimants' foregoing certain intimate associations.

This cluster of association-conditioned benefits raises definitional problems that have given the judiciary difficulty. First, who is being harmed? If the claimant's constitutional argument rests on a theory of discrimination against illegitimacy, it may make a difference whether the law is perceived as harming illegitimate children or their parents. ${ }^{123}$ Second, what is the interest at stake? When a pregnant school teacher is required to take a long maternity leave, shall we think of the rule as restricting employment or the right to procreate? When welfare assistance is proportioned to family size, but aid to any one family is limited to a specified maximum amount, does the law restrict welfare benefits or family size? If access to a state's divorce court is conditioned on one year's residence in the state, is it the freedom

121. See Lynn, Legal and Economic Implications of the Emergence of Quasi-Public Wealth, 65 Yale L.J. 786 (1956); Reich, The New Property, 73 Yale L.J. 733 (1964). First, the welfare state, with its social insurance and transfer payments and other entitlements, has largely supplanted traditional forms of wealth in the lives of many people. The law governing marital property has nothing to do with Social Security benefits or the right to live in public housing. For the vast middle class, employment is the main source not only of income but of other wealth entitlements such as health insurance, pensions, and death benefits. See Reich, supra, at 738-39. An equally important reason why marriage and the status of legitimacy are declining in their legal significance is the rapid acceleration in the last decade of the movement toward equality for women. Indeed, as I shall show later, the women's movement has had central importance, both practical and theoretical, for the emergence of the freedom of intimate association. See pp. 660-63 infra.

122. See M. GLENDoN, supra note 119 , at 78-105.

123. Compare Parham v. Hughes, 441 U.S. 347, 352-53 (1979) (upholding state statute precluding father of unacknowledged illegitimate child from suing for wrongful death of child) with Trimble v. Gordon, 430 U.S. 762, 768-70 (1977) (striking down state intestate succession statute as denial of illegitimates' equal protection rights). A case in which the Court got this subject all wrong is Fiallo v. Bell, 430 U.S. 787, 797-800 (1977) (refusing to overturn federal law that denied preferential immigration status to illegitimate child seeking preference on basis of relationship to natural father). Both Parham and Trimble considered whether the penalty was imposed on the child for a status he could not change, but in Fiallo, the Court did not raise this question. See id. at 809-10 (Marshall, J., dissenting). 
of travel that is at stake, or the interest in terminating a marriage? The Supreme Court has not yet explicitly addressed the general issue of whether it is proper to think about these questions as either/or choices. It has simply assumed that one or the other interest is the relevant one to be considered. Not surprisingky, the Court's analysis has sometimes focused on the associational-freedom-interest side, and sometimes on the side of the more material interest. ${ }^{124}$ Because the Court has not seen fit to explain its selections, it has made no effort to reconcile the resulting apparent inconsistencies.

By no means is the principle of associational choice always antagonistic to a rule emphasizing formal associational status. The decision to marry, or to legitimate a child born outside marriage, is an exercise of associational choice, and it is compatible with the choice principle to attach some legal consequences to that choice. It is altogether different when an associational status has been fastened on someone who has made no choice in the matter. To attach legal consequences to such an imposed status may, on balance, be justified in a given case; one valid justification for submerging the associational choice of one person may be the vindication of another's choice. The point is that the choice principle dictates a serious search for justification.

Seen as a constitutional puzzle, this situation seems to offer opportunities for circular reasoning on several levels. The ease of entry into a formal associational status, the ease of termination of the status, and the legal consequences of the status-all are in the control of the state. Suppose that a court must decide on the constitutional validity of a law making formal status the key to some material benefit. Part of the court's analysis, surely, must be to determine how easy it is for the claimant to obtain the status, and thus the benefit. On the other hand, suppose a court must decide on the validity of a stateimposed restriction on entry into the same status. Part of the analysis of that question will be to determine how much turns on the status. If, for instance, it makes little legal difference whether a couple are married or not, we might expect the state to argue that it can keep the barriers to entry into marriage very high without encountering constitutional difficulties. Correspondingly, if exit from marriage is

124. Compare Dandridge v. Williams, 397 U.S. 471 (1970) (focusing on loss of material benefit) with Cleveland Bd. of Educ. v. LaFleur, 414 U.S. 632 (1974) (focusing on restriction of right to procreate). 
legally easy, the argument will be that not much is lost when entry is difficult. ${ }^{125}$

The way out of these two mazes has already been indicated. ${ }^{126}$ It requires, in both instances, careful evaluation of the values at stake in the type of case before the court. In particular, attention must be paid to the value of intimate association as a self-identifying statement. Let us assume that the state has conditioned some important benefit on the claimant's being married, and also that entry into marriage is as easy as entry into a 1925 speakeasy. ("You don't have a card? OK, here's a card.") Assume also that, once the benefit has been received, exit from marriage is also eased by a no-fault divorce procedure so simple that do-it-yourself divorces are common. Should we necessarily conclude that conditioning the benefit on the claimant's marriage raises no serious constitutional issue? Would it not be preferable to recognize that for most people, marriage is not merely a bureaucratic hurdle but primarily a symbolic statement of commitment and selfidentification?

The same considerations should inform decision on the constitutionality of limitations on access to a formal associational status. Even though the status may have little material importance, or may be readily terminated, it may have immense symbolic value for the people who seek to associate themselves formally. The homosexual couple who wish to enter a formal marriage will not be looking for material benefits, or even for the pleasure of each other's company (which they already have), so much as for the opportunity to say something about who they are and to obtain community recognition of their relationship. ${ }^{127}$

Another possible circularity of argument lurks in the suggestion that the state's recognition or sponsorship of a formal status implies an undertaking, translatable into a constitutional obligation, to permit occupants of the status to fulfill the normal expectations of that status. On this reasoning, Griswold rests on the notion that marriage is a compact, not only between the individuals who marry but also between the spouses and the state, which is thereby obliged to respect

125. E.g., Wilkinson \& White, supra note 15, at 576-77. The notion seems to be that when $H$ and $W$ marry, $H$ is not obtaining much of a prize if $W$ can leave the union at will.

126. See p. 629 supra.

127. Such may have been the purpose of the plaintiffs in Doe v. Commonwealth's Attorney, 425 U.S. 901 (1976), aff'g 403 F. Supp. 1199 (E.D. Va. 1975). Plaintiffs sought a declaratory judgment that the state's sodomy law was unconstitutional in its application to two adult male homosexuals in a stable relationship. They had not been subjected to any threat of prosecution. 
the usual purposes of marriage, including the spouses' pursuit of love and its physical expression. ${ }^{128}$ This theory, with its contractual emphasis, appears to promote a reasoning that would permit the state to regulate would-be spouses' sexual intimacy by simply refusing them the status of marriage. Where marriage is involved, however, the state does not have a contracting party's choice to accept or reject the compact. ${ }^{129}$ The one most clearly established feature of the constitutional freedom of intimate association is the freedom to marry, which radically restricts the state's power to withhold the status of marriage from a willing couple. A compact that one party is compelled to enter is not much of a compact; it is, instead, a fictional middle step in a line of legal reasoning-a step that can be eliminated in the interest of economy. Justice Douglas was sometimes accused of using Occam's Razor to achieve not economy of reasoning but parsimony; ${ }^{130}$ in Griswold, however, he correctly saw that it was the freedom of intimate association, not the state's contractual obligation, that justified the Court's decision.

The logic of the freedom of intimate association-that is, the implications of the values that are the substantive components of this associational freedom-cannot be contained at the status boundaries of formal marriage or legitimacy of parentage. By no means is such status of constitutional irrelevance; indeed, because entry into a formal associational status may be of great moment as a statement of commitment or self-identification, there are occasions when the interest in a formal status is properly regarded as constitutionally "fundamental." Furthermore, there are occasions when the state may properly attach legal consequences to someone's choice to enter or refrain from entering such a status. Both sets of occasions are identifiable not by mechanical application of definitions of status, but by careful weighing of the associational values at stake in particular types of cases against the justifications asserted for their restriction.

\section{Doctrinal Perspectives}

In retrospect, the result in the Griswold case seems inescapable; the chief problem before the Supreme Court was not what to decide, but how to decide. Thus there was irony in the assignment of the Court's

128. See Wellington, supra note 87 , at $290-95$ (pursuing a line of reasoning suggested by Justice Harlan in his dissent in Poe v. Ullman, 367 U.S. 497, 553 (1961)).

129. See p. 667 infra.

130. I have joined in this complaint myself, although in an admiring article. Karst, Invidious Discrimination: Justice Douglas and the Return of the "Natural-Law-DueProcess Formula," 16 UCLA L. REv. 716, $748-49$ (1969). 
opinion to Justice Douglas, who had long been known better for his whats than for his hows. Although a number of more traditional doctrinal threads were at hand-indeed, that is Griswold's fascinationJustice Douglas chose to weave the opinion from gossamer of his own. Frowning at substantive due process, glancing in the direction of the First Amendment, and altogether ignoring equal protection, he clothed the decision in a constitutional right of privacy that has kept commentators busy ever since.

In a variety of ways, the Court subsequently has buttressed Griswold's protection of the freedom of intimate association. Wherever else this freedom may find shelter, it now has a secure anchorage in a reconstructed doctrine of substantive due process. If some of the Court's opinions in intimate-association cases are unsatisfying, one reason is that they labor to avoid the rhetoric of substantive due process, seeking instead such alternative foundations as minimumrationality equal protection ${ }^{131}$ or the doctrine of "irrebuttable presumptions." 132

Equal protection doctrine has been employed frequently by the Supreme Court in the defense of the freedom of intimate association. In fact, there is a historical sense in which today's version of that freedom is derivative from the "egalitarian revolution"133 in modern constitutional law. Were it not for the disrepute of substantive due process in the 1960s, many intimate-association cases decided in the name of equal protection might have been explained in due process terms. I do not suggest the abandonment of equal protection rhetoric in these cases; the interest in equality, particularly among equal citizens, is the main substantive value at stake in many intimate association cases. If substantive due process is often an appropriate alternative ground for deciding such cases, it will not replace equal protection but give it lateral support.

But what of the First Amendment? The intimacies threatened in Griswold were another form of expressive conduct, "the speech of loving." ${ }^{34}$ The very freedom of association that served Justice Douglas as an analogy in that case was a First Amendment freedom. Yet, despite numerous opportunities to protect intimate association by em-

131. E.g., United States Dep't of Agriculture v. Moreno, 413 U.S. 528, 533-34 (1973); Eisenstadt v. Baird, 405 U.S. 438, 447 \& n.7 (1972).

132. E.g., Cleveland Bd. of Educ. v. LaFleur, 414 U.S. 632, 649-50 (1974); Stanley v. Illinois, 405 U.S. 645, 656-58 (1972).

133. Kurland, The Supreme Court, 1963 Term-Foreword: "Equal in Origin and Equal in Tille to the Legislative and Executive Branches of the Government," 78 HARv. L. REv. 143, 145 (1964).

134. Reiman, supra note 46 , at 35 . 
phasizing its expressive aspects, the Court has chosen not to rely on the First Amendment. Why this reluctance?

Surely the reason does not lie in any logical limits to the definition of First Amendment interests. When two people marry, or decide to become parents, they express themselves more eloquently, tell us more about who they are and who they hope to be, than they ever could do by wearing armbands or carrying red flags. The decision to "come out of the closet" and avow one's homosexual association is certainly a statement of great personal importance and may also be a political act. The most obvious practical consequence of Griswold and its successor decisions is to free couples-and especially women-to express themselves through sexual intimacy without the "chilling effect" of the risk of unwanted pregnancy. ${ }^{135}$ If the First Amendment deserves interpretations that will "protect a rich variety of expressional modes," 136 there is no reason in logic for excluding the expression that is at the heart of most intimate associations.

There is a preliminary matter, however, that must be addressed before we consider the relationship of the First Amendment to the freedom of intimate association. First Amendment commentary now routinely admits self-expression to the temple of First Amendment values. ${ }^{137}$ If the Court thus far has refused to make the connection between this value and the freedom of intimate association, perhaps the reason is that the Justices have been concerned with the difficulty of containing so broad a theory of protected expression. In a very different context, Justice Stewart once warned of "the dangers that beset us when we lose sight of the First Amendment itself, and march forth in blind pursuit of its 'values." "138 Almost everything we do is expressive in one way or another, and thus to say that the First Amendment is a generalized presumptive guarantee of the liberty to do anything that has expressive aspects would be much like saying that the constitutional right of privacy guarantees "the right to be let alone."139 The First Amendment would, in short, be stretched to cover all our constitutional freedoms. ${ }^{140}$

135. See M. SANGER, supra note 90, at 229-30; Wallach, Musings on Motherhood, Marshall, Molecules: A Passage Through the Heart of Maternal Darkness from God's Creation to Man's, 6 BLACK L.J. 88, 106 (1978).

136. L. TRIBE, supra note 19 , at 579 .

137. E.g., T. EMerson, THE SysteM of Freedom of Expression 6 (1970); Baker, Scope of the First Amendment Freedom of Speech, 25 UCLA L. Rev. 964, 1017-20 (1978).

138. Columbia Broadcasting Sys., Inc. v. Democratic Nat'l Comm., 412 U.S. 94, 145 (1973) (Stewart, J., concurring).

139. See Konvitz, Privacy and the Law: A Philosophical Prelude, 31 LAw \& Contemp. Рвов. 272, 279-80 (Spring 1966). The phrase "right to be let alone," often attributed to Samuel Warren and Louis Brandeis, see Warren \& Brandeis, supra note 8, was first advanced in T. COOLEY, Liw of ToRTs 29 (2d ed. 1888).

140. The danger of such a doctrinal approach is that First Amendment doctrine 
Whatever commentators may say, the Court shows no present inclination to effect any such transformation. But to say that the First Amendment should not be replaced, even in theory, with a generalized right of self-expression is not to deny that self-expression is a value deserving a major role in evaluating claims of the freedom of intimate association. To put the matter in doctrinal terms, the First Amendment can provide analogies and perspectives that will be helpful when the courts evaluate substantive due process claims to the freedom of intimate association.

This suggestion is not new. The Supreme Court's recent inclination to revive substantive due process has waxed and waned according to the Justices' perceptions of the importance of the liberties at stake in one case or another. ${ }^{141}$ In the lives of most of us, the values of intimate association loom larger than the values of freedom of expression. Doctrinally, those associational values can stand on their own. Nevertheless, as they approach the borderlands of the First Amendment, it is entirely appropriate for the courts to scrutinize closely the state's asserted reasons for invading those values, and generally to be alert to opportunities for drawing parallels to First Amendment analysis. Moreover, some intimate-association cases implicate the First Amendment directly.

In seeking doctrinal perspectives, I begin with the First Amendment and then turn to the lessons of equal protection. I conclude by examining the revival of substantive due process as a unifying doctrinal basis for the freedom of intimate association.

\section{A. The First Amendment}

Perhaps the case exists in which there is something to be gained by perceiving an association as "merely an assembly dispersed over time and space." 142 To see intimate association in that light, however,

would become encumbered with new limits and exceptions, because some claims inevitably would be rejected. From these decisions a doctrinal infection would spread, touching even traditional First Amendment concerns. One analogy to this argument is the pro-speech case for defining obscenity out of the First Amendment; it is argued that courts should create a special definitional category of obscenity, and place it outside the Amendment's protection, to avoid letting potentially restrictive decisions on the distribution of obscene materials become precedents in other First Amendment areas. Such an argument may have informed Justice Brennan's opinion in Roth v. United States, 354 U.S. 476 (1957), holding that "obscenity" is unprotected speech. Although I think this "two-level" theory ultimately fails, see Kalven, The Metaphysics of the Law of Obscenity, 1960 SuP. CT. REv. 1, the parallel argument has force when it is directed against a view that would transform the First Amendment into a generalized protection of freedom to express oneself through one's behavior.

141. Compare Roe v. Wade, 410 U.S. 113 (1973) (abortion) and Moore v. City of East Cleveland, 431 U.S. 494 (1977) (plurality opinion of Powell, J.) (family living arrangements) with Kelley v. Johnson, 425 U.S. 238 (1976) (police hair-style regulations).

142. Baker, supra note 137, at 1032 (italicized in original). 
strains the bonds between doctrine and life, conjuring up the image of a lover who sits up and says, "I suppose you're wondering why I've called this meeting." Yet in this very context there is something to be learned, as Justice Douglas saw in Griswold, from the body of doctrine protecting the First Amendment freedom of association.

First, there is the analogy to First Amendment doctrine governing state-imposed sanctions on membership in political organizations. ${ }^{143}$ That doctrine severely restricts government's power to punish or otherwise disadvantage members of political associations. Such sanctions can be imposed only if the state satisfies a tough formula that protects associational freedom unless the state can demonstrate a high likelihood of some grave harm. The formula requires not only knowing, active membership in an organization that has illegal aims but also the specific intent to bring those aims to fruition. ${ }^{144}$ This formula is now seen as a particularized version of the proposition that courts must scrutinize closely the means employed to achieve even a governmental interest whose compelling importance is conceded, when the regulation in question seriously impedes the freedom of political association. ${ }^{145}$

The utility of this analogy does not depend on any notion that intimate association and political association are constitutional equivalents. ${ }^{140}$ There is force in the analogy if the two kinds of association simply involve values that are substantially similar and that deserve comparable weight in the process of judicial interest-balancing. By these standards, the freedom of intimate association measures up rather well against the freedom of political association. ${ }^{147}$ Perhaps intimate association cannot claim a full share in "the firstness of the First Amendment"; ${ }^{148}$ it is a close enough relative of political association, however, to deserve careful judicial scrutiny of any justifications asserted for restricting it in any nontrivial way. ${ }^{149}$

143. The decision that best summarizes the doctrine, which crystallized in the mid1960s, is Keyishian v. Board of Regents, 385 U.S. 589 (1967) (mere knowing membership without specific intent to further organization's unlawful aims is not ground for sanctions, under First Amendment).

144. E.g., id. at 602-04.

145. See Elrod v. Burns, 427 U.S. 347, $358-59$ (1976).

146. Cf. Baker, supra note 137 , at 1031-33 (right of assembly is logical basis of right of association; both are sources of power).

147. In Professor Tribe's words, “once one asks why self-government and political participation are to be valued," a typical response will be that "political participation is valuable in part because it enhances personal growth and self-realization." $L$. TRIBE, supra note 19, at 578. See generally Tribe, Toward a Metatheory of Free Speech, 10 Sw. U.L. REV. 237, 241 (1978).

148. See Cahn, The Firstness of the First Amendment, 65 YALE L.J. 464 (1956).

149. A related parallel between intimate association and political association was recognized by Justice Douglas in his Griswold opinion, when he analogized the interests 
The marital association's freedom can also draw on another First Amendment analogy, the law protecting religious freedom. Under current constitutional doctrine, a quarrel over the disposition of church property must be left to the authoritative religious tribunal.150 To compare this doctrinal development with the law's hands-off attitude in disputes between spouses may seem to take us to a supernal level of abstraction, but the analogy is useful. The law stays out of church disputes for fear that the hand of the state may fall not only on religious doctrine but on the communion of the association's members. Of course, when the state, pursuing the goal of intra-marital communion, leaves spouses to work out their own dispute resolutions, much depends on the structure of authority in the marriage..$^{151}$

First Amendment doctrine continues to be instructive in the intimate-association context even when we go beyond the analogies of political and religious association. If the state seeks to regulate expressive conduct within an intimate association, under prevailing First Amendment doctrine another double-edged question must be asked before analysis can proceed further: Is the state regulating the conduct to prevent the expression of a particular idea, or to prevent some harm that it fears will flow from the expressive aspects of the conduct? If the answer to either part of this question is Yes, then the state bears an extremely heavy burden of justification of its regulation. ${ }^{152}$ The initial question can be translated into the context of intimate association: When the state forbids or otherwise burdens a

in the privacy of the two forms of association. The decision on which he relied most heavily, NAACP v. Alabama, 357 U.S. 449 (1958), had protected the members of a political association against disclosure of their membership. In contrast, married couples who seck to use contraceptive devices are interested in quite another form of privacy. See p. 634 supra. Some persons may want to keep the facts of their intimate associations private-a film star may not want his marriage revealed, for example-but that was not the Griswold case. Nonetheless, the analogy to the freedom of political association was apt. The point of the $N A A C P$ case was that informational privacy was necessary to the effective functioning of the association in Alabama in the 1950s. In Griswold, the Court similarly recognized informational privacy's instrumental importance in promoting the caring, intimacy, and expression that are indispensable to the normal functioning of an association such as marriage. See p. 634 supra. Thus Griswold was not merely "a case about governmental snooping," as suggested in Ely, supra note 90, at 930.

150. E.g., Serbian Orthodox Diocese v. Milivojevich, 426 U.S. 696 (1976); Presbyterian Church in the United States v. Mary Elizabeth Blue Hull Memorial Presbyterian Church, 393 U.S. 440 (1969); Kedroff v. St. Nicholas Cathedral, 344 U.S. 94 (1952). See generally Note, Judicial Intervention in Disputes Over the Use of Church Property, 75 HARv. L. REv. 1142 (1962).

151. See Powers, supra note 81, at 70-79 (arguing that state refusal to intervene in intra-marital affairs helps maintain dependency of women).

152. See L. Tribe, supra note 19, at 580-88; Ely, Flag Desecration: A Case Study in the Roles of Categorization and Balancing in First Amendment Analysis, 88 Harv. L. REv. 1482, 1496-1502 (1975); Nimmer, The Meaning of Symbolic Speech Under the First Amendment, 21 UCLA L. REv. 29, $44-46$ (1973). 
form of intimate association, is it doing so in order to discourage the association's expressive aspects?

For example, whatever may have been the original purposes of laws forbidding homosexual sex, ${ }^{153}$ it seems clear that today one of the chief concerns underlying the maintenance of those laws is a concern to regulate the content of messages about sexual preference. It is said that the state, by repealing its prohibition on homosexual conduct, will itself be seen as making a statement approving that conduct. ${ }^{15 t}$ The selective enforcement of these laws lends credence to the notion that one of the main policies being pursued is the suppression of expression. ${ }^{155}$ The laws are rarely enforced against behavior carried on entirely in private; it is those persons who advertise their sexual preferences by frequenting gay bars and the like, or who openly display their homosexual affections, who are likely to be punished. ${ }^{156}$ The immediate practical effect of such a law's enforcement is thus to penalize public expression. And that public expression itself, as I have said, may be a political act. ${ }^{15 \tau}$

Thus, both by analogy and in direct application, First Amendment doctrine cautions us to be sensitive to the need to protect intimate associations that are unconventional or that may offend a majority of the community. Such associations are the most likely to be regulated with an uneven hand. Just as equality is a central principle in the First Amendment, ${ }^{158}$ so it must be in protecting the expressive aspects of intimate association.

153. On this subject, see Richards, supra note 15 , at 978.81 .

154. See, e.g., Wilkinson \& White, supra note 15, at 593-96. Moreover, it is argued that "it is safe to assume that removal of criminal sanctions from private acts would lead to more open homosexuality ...." Id. at 594 (emphasis added).

I55. Consider the effect of a state sodomy law applied to private sexual conduct between consenting adults of the same sex. Not only is the forbidden conduct expressive; for a homosexual, a violation of the law is the principal form that a sexual expression of her love can take. The total denial of this expression thus invades the associational values of intimacy, caring, and commitment to a degree that exceeds the invasions condemned in Griswold and Eisenstadt. But it is the homosexual's affirmation of self that suffers the most. Because of the risks attending public knowledge of her intimate relationship, she is under constant pressure to offer to the world a picture of herself that she knows to be false. In the case posed, the forbidden sexual conduct may be valued for its own sake, but it is valued primarily for its expressive content.

156. See note 116 supra. It is the open avowal of one's homosexual status that typically leads to such noncriminal sanctions as loss of employment. See, e.g., Acanfora v. Board of Educ., 491 F.2d 498, 500 (4th Cir. 1974) (transfer of public school teacher).

157. See Gay Law Students Ass'n v. Pacific Tel. \& Tel. Co., 24 Cal. 3d 458, 488, 595 P.2d 592, 610, 156 Cal. Rptr. 14, 32-33 (1979) ("[O]ne important aspect of the struggle for equal rights is to induce homosexual individuals to 'come out of the closet,' acknowledge their sexual preferences, and to associate with others in working for equal rights.")

158. See Karst, Equality as a Central Principle in the First Amendment, $43 \mathrm{U}$. CHI. L. REV. 20 (1975). 
A final teaching deserves transfer from our First Amendment lore to the freedom of intimate association: If a law conditions a benefit on the presence or absence of some intimate association or some associational status, the validity of that condition should be tested in consideration of the degree to which it interferes with the freedom of intimate association, and not merely as if the law dealt only with the dispensing of money, or employment, or some other material benefit. The point has obvious relevance when the question is whether a benefit can be denied without a hearing. The freedom of intimate association is unquestionably a "liberty" interest,, ${ }^{159}$ and the claimant is thus entitled to procedural due process whether or not the benefit at stake is a "property" interest. ${ }^{100}$ Furthermore, when the courts do their substantive interest balancing in such cases, whether or not they explain that operation in terms of a particular standard of review, they should weigh the associational interests on the claimant's side of the balance, and not merely the material benefit he or she is claiming. ${ }^{161}$

\section{B. Equal Protection}

The recognition of a constitutional freedom of intimate association has been hastened by two egalitarian trends in our recent social history. One is the acceleration of the movement toward racial equality, which has brought with it new awareness and acceptance of a cultural diversity that goes well beyond differences based on race. The other is the sudden success of the feminist movement in engaging national attention and changing the attitudes of men and women alike toward questions of "woman's role." These two streams of social change are fed by a common egalitarian rhetoric; it is no accident that the call for equality often finds expression in words like "freedom" or "liberation." The freedom to choose one's place in society, rather than accept an inferior status as Nature's legacy, is both a symbol of equality and an effective instrument for attaining it. There is nothing incongruous about protecting the freedom of intimate association through application of the equal protection clause.

A good beginning point is the fact of diversity. To say, in the words of an eminent sociologist, that higher percentages of illegiti-

159. See Smith v. Organization of Foster Families for Equality and Reform, 431 U.S. 816,842 (1977).

160. In some cases, of course, due process may not require a prior hearing, in advance of the governmental action in question. See Parham v. J.R., 99 S. Ct. 2493 (1979).

161. A case in which the Court utterly failed to appreciate this point is Village of Belle Terre v. Boraas, 416 U.S. 1 (1974). See pp. 687-89 infra. 
macy among nonwhites ${ }^{162}$ evidence "social distintegration"103 is to state a value preference. Even in the first half of this century, when an idealized picture of "housewife marriage" largely defined the range of the acceptable in intimate association, that picture was only part of our social reality. ${ }^{164}$ Mere recital of divorce rates, or the number of unmarried couples who live together, is enough to remind us that the facts of associational life, and not merely our perceptions of them, have altered significantly in the past two decades. ${ }^{105}$ It is safe to predict that other forms of intimate association will go forth and multiply and attain respectability, as they have done in recent memory. The "moral flux"166 implicit in this change should be seen neither as the effluent of social sickness nor as the flow of convention from one dominant associational mode to another; it is rather the proliferation of acceptable forms of intimate association. Looking at our associational patterns in the 1960 s and 1970s, we have seen the future, and it diversifies. ${ }^{167}$

It would be a mistake to think of race as the chief variable in the

162. See The Future of THE FAMiLY (L. Howe ed. 1972):

What is invariably in mind [when we consider "the family"], we will find, is a white, middle-class, monogamous, father-at-work, mother-and-children-at-home family living in a suburban one-family house. This is a definition that now effectively excludes more than half the population.

Id. at 11 . In $1976,7.7 \%$ of white American babies were illegitimate; among nonwhites the comparable figure was $45.2 \%$. U.S. Public Health Serv., 26 Monthly Vital Statistics REP. 17 (1978 Supp.).

163. R. Aron, supra note 11 , at 121 .

164. The picture omitted not only the associational patterns outside the majoritarian cultural mainstream, but also those forms of intimate association that were treated as skeletons in a family's closet. The fact that this metaphor now seems quaint measures the distance we have come, not so much in our consciousness of associational diversity as in our acceptance of it.

165. The popular press has these modulations in mind when it speaks of "the family in transition." This transition exists only as a cluster of statistical averages, however. Particular families form or dissolve, grow or shrink, unify or scatter. "The family," even in its 1920 idealized model, will no doubt continue co exist, both as ideal and fact, for millions of Americans. Changes over time will not transform "the family" from one pattern to another, except in the composite confections of some sociologists.

166. The term is Professor Tribe's. See Tribe, Structural Due Process, 10 H.Arv. C.R.C.L. L. REv. 269, 308 (1975). On the variety of forms of man/woman relationships, see C. Rogers, Becoming Partners: Marriage and Its Alternatives (1972).

167. We have no reason to expect major changes in this line of development. Urbanization and industrialization are here to stay; families are not likely to regain their lost economic functions; the "wife economy," see Hardwick, Domestic Manners, 107 Dafdalus 1,10 (Winter 1978), now obsolete, is unlikely to make a comeback; increased longevity will continue to place strains on lifetime marriage; our society will not revert to yesterday's as sumptions about "woman's role"; racial and ethnic minorities will not again accept the notion that their forms of intimate association are merely pathological. See C. STACK, All OUR Kin: Strategies for Survival in a Black Community 108-23 (1974) (analysis of strong ties in kinship networks of urban black families). 
diversity of American family relationships. ${ }^{168}$ The recent rapid changes in the status of women are beginning to make their own contribution to the diversity of family relationships. Women increasingly find that "housewife marriage"160 is not the only acceptable path and see a variety of alternatives open to them. Those who do choose marriage need not choose motherhood, either immediately or in the longer term. Conversely, those who choose motherhood need not marry, if the legal disabilities associated with illegitimacy are minimized. The libertarian slogan of the abortion-rights movement, "Choice," is also an egalitarian claim. ${ }^{170}$ For a significant number of couples, the experience of living together before marrying also imprints their marriages with an egalitarian stamp. ${ }^{171}$ After they have married, what has changed? The marriage is apt to be seen mainly for its symbolic content. Both partners continue to work and contribute to the household income. If they decide to have children, it will be a joint decision. Perhaps the wife's share of the family income will have to be forgone for a time, but the length of that time is itself largely a matter of the couple's choice. The pattern of joint decisionmaking is not likely to disappear, even if the couple choose for the wife to be a full-time mother for a number of years.

168. Even so, race has played a conspicuous role in making us conscious of this diversity, and increasingly receptive to it. If the guarantee of equal protection protects hippies against deliberate legislative hostility, even when the animus is packaged in terms of support for a traditional kind of household, e.g., United States Dep't of Agriculture v. Moreno, 413 U.S. 528 (1973) (law denied food stamps to households containing unrelated individuals), the decision's doctrinal roots lie in the civil rights movement.

169. See M. Glendon, supra note 119 , at 114 (term describing marriage in which husband is breadwinner and wife takes care of home and children).

170. Professor Ely seems to me to have the causal sequence backwards when he says that classification by sex is coming to be treated as suspect, not because women need protection as a disadvantaged group but because the relevant cases are "a perceived part of the sex-children cluster that the Court has asserted as a fundamental set of values." Ely, The Supreme Court, 1977 Term-Foreword: On Discovering Fundamental Values, 92 HaRv. L. REv. 5, 12 (1978). From my perspective, it looks as though the most important decisions promoting the freedom of intimate association are being carried along on a tide of feminism.

171. Consider the case of an unmarried couple who live together in what they regard as a trial marriage, the sort of thing our parents talked about in the $1920 \mathrm{~s}$ and our children practiced in the $1970 \mathrm{~s}$. When the couple begin to live together, equality is the natural order in their relationship. Both are employed; there is no easy assumption of "breadwinner" and "housewife" roles. When the couple do marry, one common reason is that they want to have children and thus choose to adopt a formal status that will satisfy those who may disapprove of the status of illegitimacy. Another reason, often intertwined with the first, is that the couple wish to make a statement-to the world at large, and to themselves-about who they are and who they have chosen to be. Concededly, the egalitarian aspects of this scenario are primarily valid for middle-class couples and especially for young professionals. The marriage of such a couple presents its own difficulties, some of which interfere with the values of intimate association. See Kay, Legal and Social Impediments to Dual Career Marriages, 12 U.C. DAvis L. REv. 207 (1979). 
If marriage and the traditional family are the archetypal associations protected by the emergent freedom of intimate association, it is easy to see how the principle of equality presses for extension of that freedom to other relationships. The tendency in the development of new constitutional doctrine is for a clear-cut paradigm case to be identified, and for institutional litigators, scholars, and other lawyers to search for analogies that are "close enough" in functional or doctrinal terms to justify application of a similar principle. The extension of the freedom of intimate association from marriage to marriagelike relationships follows naturally, once we focus on the values at stake in the two forms of association. Indeed, to draw the line at formal marriage for some legal purposes seems an arbitrary discrimination against an unmarried couple, whose relationship may occupy a place in their lives closely similar to the place occupied by marriage in the lives of a married couple.172 And if, after Griswold, the state could not constitutionally deny access to contraceptive devices to an unmarried couple living together, what would justify denying access to a single woman who wished to affirm her feelings by means of sexual expression without risking pregnancy?

The interest in equality is at the core of Eisenstadt $v$. Baird ${ }^{173}$ and there is good equal protection sense in the Court's decision. Eisenstadt follows from Griswold, because the values of intimate association in the two cases are so closely parallel. The same equal protection reasoning, however, necessarily undermines the constitutionality of both fornication laws and laws generally prohibiting the sale of contraceptives. Eisenstadt's result rests easily on an equal protection founda-

172. I have deliberately used the phrasing of the Court's opinion in United States v. Seeger, 380 U.S. 163, 176 (1965) (conscientious-objection exemption is proper when sincere belief "occupies in the life of its possessor a place parallel to that filled by the [orthodox belief in] God of those admittedly qualifying for the exemption"). An egalitarian impulse is one of the main features of the Establishment Clause.

173. 405 U.S. 438 (1972). In that case, an advocate of planned parenthood was convicted for giving a package of contraceptive foam to a young unmarried woman. But see id. at 462 (White, J., concurring) (record failed to establish woman's unmarried status). State law made it a crime to give any contraceptive to an unmarried person for the prevention of pregnancy, but permitted married persons access to contraceptives for this purpose. In a federal habeas corpus proceeding, the Court held that the state law, viewed as a prohibition on contraception, violated the equal protection rights of single persons because it failed the test of minimum rationality. The Court assumed for argument that the state could prohibit fornication and said that it need not face the question whether the state could forbid altogether the sale of contraceptives. Instead, it chose to rest its decision on a rationale that was technical and unsatisfying, using Griswold as no more than a stage prop and begging the question whether the state could distinguish between single and unmarried persons. Id. at 447; see Gunther, The Supreme Court, 1971 Term-Foreword: In Search of Evolving Doctrine on a Changing Court: A Model for a Newer Equal Protection, 86 HARv. L. REv. 1, 34-36 (1972). 
tion, even without considering the decision's implications for the status of women.

The key to this analysis, as to any analysis of the freedom of intimate association, is an inquiry into the ways in which the values of intimate association come into play in a given factual or doctrinal context. When the issue is one of equal protection, however, another ingredient must be added to the analysis before we can evaluate the strength of the constitutional claim. The substantive heart of the Fourteenth Amendment, as I have argued elsewhere, ${ }^{174}$ is a principle of equal citizenship, a presumptive guarantee of the right to be treated by the organized society as a respected, responsible, participating member. Some of the values in intimate association are closely bound up with a person's sense of self: caring, commitment, intimacy, self-identification. When the state seriously impairs those values by restricting intimate association, the equal protection clause is at its most demanding, insisting on justifications of the highest order if the state is to be allowed to persist. The equal citizenship principle serves in the context of intimate association as it serves elsewhere, not as a result-producing formula but as a substantive guide to the interest balancing that the Supreme Court has recently practiced in the name of a variable standard of review.

Many of the equal protection issues that have arisen in the context of intimate association have centered on the consequences that can properly be attached to formal associational status. Eisenstadt was such a case, and so are the illegitimacy cases, from Levy v. Louisi$a^{a n a^{175}}$ to Parham v. Hughes. ${ }^{176}$ A different but related problem would be raised by an attack on a state's refusal to recognize the status of homosexual marriage or to provide a comparable alternative status. Viewed in the perspective of equal protection, all these cases require a similar analysis: Which of the values of intimate association are impaired? Does the formal status in question have importance as a symbol, or as a key to some benefit, or both? Does the impairment of associational values imply some serious invasion of the equal citizenship interests of respect, responsibility, and participation? If so, has the state sufficiently justified that invasion?

As the foregoing examples suggest, the chief concern of the equal protection clause in intimate association cases will be the protection of unconventional associational arrangements against legislative in-

174. See Karst, supra note 20.

175. 391 U.S. 68 (1968).

176. 441 U.S. 347 (1979). 
terference stemming from malevolence or from the same sort of "selective sympathy and indifference"177 that characterize much racial discrimination. Most of the Supreme Court's equal protection decisions in the area of intimate association involve just such cases; the unconventional are the most likely victims of legislative discrimination. In a society that is culturally diverse, expressing that diversity in a rich variety of family forms and other personal relationships, the constitutional rights to freedom and equality turn out to offer much the same protections for the interests in intimate association.

\section{G. Substantive Due Process}

Considering the tarnished reputation of substantive due process in the years before Griswold was decided, it is not surprising that Justice Douglas disclaimed reliance on it. Even today there may be some strategic value in such a disclaimer; in Roe $v$. Wade, ${ }^{178}$ Justice Blackmun's embrace of substantive due process as the foundation of the new right of privacy was anything but wholehearted. ${ }^{179}$ After so many years of heaping scorn on Lochner v. New York, ${ }^{180}$ the Court has not found it easy to admit that substantive due process has returned.

We pay a price for this judicial evasion. Calling the rights in Griswold and Roe rights of privacy invites the rejection of comparable claims on the ground that, after all, they do not rest on any concerns about control over the disclosure of information. Roe itself was criticized on this score. ${ }^{181}$ What was at stake in the two cases, as Justice Stewart said forthrightly in Roe, was "freedom of personal choice in matters of marriage and family life," which is "one of the liberties

177. Brest, The Supreme Court, 1975 Term-Foreword: In Defense of the Antidiscrimination Principle, 90 HaRv. L. REv. 1, 7 (1976).

178. 410 U.S. 113 (1973).

179. Id. at 153 ("This right of privacy, whether it be founded in the Fourteenth Amendment's concept of personal liberty and restrictions upon state action, as we fecl it is, or, as the District Court determined, in the Ninth Amendment's reservation of rights to the people....").

There is no need to contrast substantive due process with the Ninth Amendment, as Justice Blackmun did in Roe. Surely the relevance of the Ninth Amendment in these cases lies in its recognition that there are such things as rights that are not explicitly spelled out in the Constitution. Justice Goldberg made this point in his concurrence in Griswold, 381 U.S. at $487-99$. The next step, if you are not put off by the very idea of substantive due process, is to accept that doctrine as the appropriate receptacle for the rights whose existence the Ninth Amendment acknowledges. Professor Ely, who is put off by substantive due process, would not take that next step even though he recognizes the force of the general proposition that the Ninth Amendment "was intended to signal the existence of federal constitutional rights beyond those listed elsewhere in the document . . .." Ely, Constitutional Interpretivism: Its Allure and Impossibility, 53 IND. L.J. 399, 445 (1978).

180. 198 U.S. 45 (1905).

181. See Ely, supra note 90 , at 928-30. 
protected by the Due Process Clause of the Fourteenth Amendment."182 All that need be added to this formulation is the recognition that the freedom in question goes beyond the relationships of marriage and family to other forms of intimate association.

Even the severest critics of the current revival of substantive due process appear to recognize that it is here to stay, at least for the near future. ${ }^{183}$ In the rest of this article, I take that prediction for granted. Furthermore, I expect that the cutting edge of this new/old doctrinal development will continue to be the freedom of intimate association, as it has been in the line of cases from Griswold to Moore v. City of East Cleveland..$^{184}$

John Hart Ely rightly identifies the task of commentators as the development of a "principled approach to judicial enforcement of the Constitution's open-ended provisions ...."185 In his view, the judiciary can properly seek to assure "broad participation, not simply in the processes of government but in the benefits generated by those processes as well."186 I have argued elsewhere that these two clusters of considerations coalesce in the substantive core of the Fourteenth Amendment, the principle of equal citizenship. ${ }^{187}$ If the famous footnote four in United States $v$. Carolene Products ${ }^{188}$ legitimizes special judicial solicitude for the status of women and racial or ethnic minorities, then the freedom of intimate association, in its most typical applications, fits comfortably into the footnote's doctrinal matrix.

182. 410 U.S. at 169.

183. See, e.g., Monaghan, Professor Jones and the Constitution, 4 VT. L. REv. 87, 92 (1979). Substantive due process, Heaven knows, has had its detractors throughout its recent revival. Justice Black, dissenting in Griswold, correctly saw the decision as a reflection of a "natural law due process philosophy" that the Court had purported to abandon a generation earlier. 38I U.S. at 524. Yet his opinion is misleading in its suggestion that natural law was somehow a short-lived phenomenon of the early 20th century. In fact, as shown by his quotation from Justice Iredell's famous dissent in Calder v. Bull, 3 U.S. (3 Dall.) 386, 399 (1798), natural law has long been present in our constitutional consciousness. As brooding omnipresences go, it has been remarkably resilient. Crush it to earth, and it rebounds in another doctrinal form. Substantive due process doesn't die, and it doesn't fade away; it just changes its name from time to time. Thus the contract clause gives way to economic due process, which "dies" only to be replaced by the contract clause. See, e.g., Allied Structural Steel Co. v. Spannaus, 438 U.S. 234 (1978); United States Trust Co. v. New Jersey, 431 U.S. I (1977). The "new" equal protection gives way to "irrebuttable presumptions" and finally to substantive due process itself. See Moore v. City of East Cleveland, 431 U.S. 494 (1977).

184. 431 U.S. 494 (1977).

185. Ely, supra note 179 , at 448 .

186. Ely, supra note 170 , at 5·6. See generally J. Ely, Democracy and Distrust: A Theory of Judicial Review (1980).

187. Karst, supra note 20.

188. United States v. Carolene Prods. Co., 304 U.S. 144, 152 n.4 (1938) (suggesting "more exacting judicial scrutiny" of legislation that restricts political processes or that may result from "prejudice against discrete and insular minorities"). 
Finally, in elaborating the doctrine of intimate associational freedom, judges have available to them a standard form of legal reasoning, the use of analogy. ${ }^{189}$ I have suggested, for example, that the First Amendment offers a series of analogies that helps courts formulate and apply substantive due process doctrine in the context of intimate association. What gives force to any doctrinal analogy is its ability to clarify the common substantive values at stake in the cases under comparison. This Article's remaining task is to illustrate how the freedom of intimate association can serve this function of illumination.

\section{The Organizing Principle Illustrated}

In the pages that follow, as we examine the operation of this freedom of intimate association in a number of factual settings, I reach some conclusions that no one can realistically expect courts to adopt in the near future. It bears emphasis, therefore, that the advantages of the freedom as an organizing principle do not depend on anyone's sharing my judgment as to the weights appropriately assigned to the countervailing interests in any given case.

The freedom of intimate association can serve a similar function outside the domain of constitutional law. Recent years have seen the influence of the values of intimate association across the entire range of lawmaking activity: the enactment or repeal of statutes ${ }^{100}$ and the adoption of new administrative regulations; ${ }^{191}$ the formulation of new interpretations of old statutes; ${ }^{192}$ the rejection of old judge-made rules $^{193}$ and the development of new ones: ${ }^{194}$ and the use of associa-

189. See E. Levi, An Introduction to Legal Reasoning 57-74 (1949).

190. Consider, for instance, the enactment of no-fault divorce laws, or the repeal of laws making criminal sexual conduct involving consensual, adult homosexuals. Beginning in 1969, twenty-one states have decriminalized such conduct. See Rivera, Our StraightLaced Judges: The Legal Position of Homosexual Persons in the United States, 30 Hastrngs L.J. 799, 950-51 (1979).

191. Consider, for instance, the amendment of federal civil service regulations to provide that a person shall not be disqualified from federal employment solely on the basis of homosexual conduct. 5 C.F.R. $\$ 731.202(\mathrm{~b})$ (1979). California's Department of Health Services has proposed regulations (in response to federal administrative requirements) governing sterilization. See Nelson, Doctors Disagree on Sterilization Rules, Los Angeles Times, Aug. 2, 1979, part 1, at 26, col. 1.

192. Consider, for instance, the reinterpretation of California's "lewd or dissolute conduct" statute to exclude the solicitation of sexual acts to be performed in private. Pryor v. Municipal Court, 25 Cal. 3d 238, 599 P.2d 636, 158 Cal. Rptr. 330 (1979). See generally Note, Title III and the Classic Triangle: Should the Immunity Doctrine Apply to Interspousal Electronic Surveillance? 12 CREIGHTON L. REv. 1209 (1979).

193. Consider the abandonment of breach-of-promise tort recovery, see Brown, supra note 36 , or the abandonment of interspousal tort immunity, see Shook v. Crabb, 281 N.W.2d 616 (Iowa 1979).

194. E.g., Marvin v. Marvin, 18 Cal. 3d 660, 557 P.2d 106, 134 Cal. Rptr. 815 (1976). 
tional values to guide the exercise of administrative and judicial discretion. ${ }^{195}$ Some of these nonconstitutional developments can be viewed as indirect results of the emergence of the constitutional freedom of intimate association. Even those lawmaking developments that are not traceable to the constitutional freedom serve to give that freedom support by contributing to the redefinition of the moral setting within which constitutional doctrine grows.

Because it is the constitutional doctrine that is the focus of this Article, I shall conclude with an effort to illustrate the ways in which the freedom of intimate association can inform the process of judgment in constitutional cases. Five overlapping subject areas provide the illustrations.

\section{A. The Right to Marry}

The "right to marry" decision of the Supreme Court in Zablocki v. Redhail ${ }^{106}$ produced six opinions-on the high side even for a persistently fragmented Court-including, happily, one opinion for the Court. The decision was easy enough; indeed, Justice Rehnquist's lone dissent serves primarily to heighten the sense of the decision's correctness. Wisconsin sought to measure the financial qualifications of a certain type of candidate for marriage: a resident parent who had been ordered by a court to support a child not in his or her custody. Such a person could not marry without a court's permission, which was to be granted only when the candidate had proved compliance with the support obligation and had shown that the children in question were not likely to become public charges. Here was a law in which nearly anyone could find a fatal flaw. What seriously divided the Court was not the result, but whether there was such a thing as a "right to marry," and, if so, what that right might mean.

Of course there is a right to marry. Loving $v$. Virginia ${ }^{197}$ was not just an equal protection decision about racial discrimination; it rested on an alternative substantive due process ground that the Court in Zablocki properly cited with approval. ${ }^{198}$ The question is what the right to marry implies. All would agree-even Justice Rehnquist, I suppose-that an arbitrary denial by the state of the freedom to marry would violate the Fourteenth Amendment. ${ }^{190}$ On the other hand,

195. Consider, for instance, decisions on child custody, or on sentencing, probation, and parole.

196. 434 U.S. 374 (1978).

197. 388 U.S. I (1967).

198. 434 U.S. at 383 .

199. Justice Stewart, who rejected the notion of a constitutional right to marry, made this point when he conceded that the state could not constitutionally forbid marriage by one who had not paid traffic fines. Id. at 393 (Stewart, J., concurring). 
Justice Marshall, writing for the Court in Zablocki, agreed that the right to marry did not override the state's power to impose "reasonable regulations that do not significantly interfere with decisions to enter into the marital relationship." 200 This qualification was followed by a citation to the Court's unanimous decision, earlier in the same term, in Califano v. Jobst. ${ }^{201}$ That decision upheld a provision of the Social Security Act terminating a dependent child's benefits when the child marries a person who is not also entitled to benefits. ${ }^{202}$

It doesn't matter whether such cases are analyzed in equal protection terms, as in the Court's Zablocki opinion, or in substantive due process terms, as in Justice Stewart's concurrence. Either doctrinal approach will serve whenever the law draws a classification that restricts the exercise of a significant liberty. The question that matters is this: How much is to be demanded of the state in justifying its restriction? Justice Powell complained that the Court had not provided "any principled means for distinguishing between the two types of regulations." ${ }^{203}$ As the Court's opinion and the Chief Justice's concurrence shows, the Court's test flirts with the old distinction between "direct" and "indirect" burdens, which has been out of vogue in state-regulation-of-commerce cases for more than thirty-five years. ${ }^{204}$ Yet, in my judgment, the Court's decision to subject the law in $\mathrm{Za}$ blocki to "critical examination," demanding justification by reference to some "compelling state interest," was sound. Then what about Jobst?

200. Id. at 386 .

201. 434 U.S. 47 (1977).

202. Id. at 48 (codified at 42 U.S.C. $\$ \S 402(\mathrm{~d})(1)(\mathrm{D})$, (d)(5) (1976)).

203. 434 U.S. at 396 (Powell, J., concurring). Justice Stevens, perceiving "tension" between the Zablocki and Jobst opinions, argued that Jobst had in fact involved a regulation "significantly interfering" with the decision to marry, and that the line between valid and invalid state restrictions on marriage did not follow the path traced by that phrase. Instead, he emphasized the irrationality of the state's apparent reliance on sex-role stereotypes and its "clumsy and deliberate legislative discrimination between the rich and the poor," id. at 406 (Stevens, J., concurring), and agreed that the law denied the equal protection of the laws. Justice Stewart, similarly decrying the irrationality of "telling people they may not marry because they are too poor," concluded that the law denied due process. Id. at 395 (Stewart, J., concurring). Justice Powell, finding both equal protection and due process violations, applied an intermediate standard of review borrowed from the most recent sex discrimination cases. Id. at 400 (Powell, J., concurring). Justice Marshall, for a majority of five, concluded that the law did "interfere directly and substantially with the right to marry." Id. at 387. Thus he subjected the law to the strict scrutiny that has been used by the Court in equal protection cases involving fundamental interests, and found it wanting. The Chief Justice, who joined the Court's opinion, added his own concurrence to say that, contrary to Justice Stevens's suggestion, the Social Security provision in Jobst had not involved any significant interference with the choice to marry, but "at most, had an indirect impact on that decision." Id. at 391 (Burger, C.J., concurring).

204. See Southern Pac. Co. v. Arizona, 325 U.S. 761 (1945) (following Dowling, Interstate Commerce and State Power, 27 VA. L. REv. 1 (1940)). 
We need help in these cases, and we aren't going to find it in conclusory statements about the appropriate standard of review. The only way to make sense of the equal protection and substantive due process jurisprudence of the future is to seek guidance in substantive values. And that is where the freedom of intimate association enters this dimly lit stage. The material benefits that may be associated with marital status (or, as in Jobst, with the unmarried status) may be one consideration for a couple to take into account when they decide to marry. Unlike the other myriad considerations in the couple's minds, it has the advantage of being rather precisely quantified. Furthermore, in most of the cases covered by the statute in Jobst, an individual's loss of Social Security benefits is compensated by the gain of a marriage partner who will be able to provide some financial support. ${ }^{205}$ As Justice Marshall and the Chief Justice suggested in their Zablocki opinions, only rarely will a material benefit so modest as a child's Social Security allowance play an important role in influencing the decision whether to marry. In contrast, the state in Zablocki forbids a poor person or even a person of modest means to marry because he or she will not be able to present the requisite proof of future ability to provide enough support to take the child off the rolls of public assistance. In both Jobst and Zablocki, a money cost is attached to the decision to marry; in Zablocki, that cost will be prohibitive in most cases covered by the statute. ${ }^{206}$

To say that the distinction between losing the right to marry and losing a monthly Social Security benefit is a matter of degree is only to recognize that Zablocki and Jobst both exemplify the interest balancing that characterizes decisions guided by equal protection and due process doctrine. We need not pretend that the loss of a Social Security benefit is trivial in order to conclude that Jobst was rightly decided. 207

In Zablocki, however, the denial of the right to marry invades in

205. Unhappily, the facts of Jobst itself did not fit this description. The Social Security beneficiary married a woman who was disabled, but not receiving Social Security benefits. She was receiving state welfare assistance. 434 U.S. at $48 \mathrm{n}$.I.

206. Mr. Redhail was behind in his support payments by more than $\$ 3,700$. Further, it was stipulated that his child would continue to be a public charge (i.e., eligible for welfare benefits) even if he were current in his support payments. 434 U.S. at 378 .

207. Once it is agreed that there is a substantial justification for the general rule terminating dependency benefits upon marriage, the question is whether Congress can make an exception for marriages between two Social Security beneficiaries without also making an exception for other cases of provable need. Jobst did involve such need. See note 32 supra. It makes eminent sense to relieve against the double loss of benefits that would otherwise result when beneficiaries marry, and an exception so limited avoids the need for individualized investigation of need, not only in all cases of termination that arise each year, but periodically thereafter in every such case. 
an extremely severe way the values in intimate association. The couple there could, of course, live together in intimacy, and even have children, with little fear of prosecution under Wisconsin's fornication statute. ${ }^{208}$ What is involved is something less tangible and more important: the values of self-identification and commitment. The couple in Zablocki wanted to marry partly because the woman was pregnant; the complaint alleged that they wanted to marry before the child was born. They were concerned, that is, about appearances and about status, their own and their child's. Those concerns are both real and important, long recognized by the law in areas such as defamation, and obviously a principal focus for the self-identification of the man and woman who wanted to marry. ${ }^{209}$ With or without the doctrinal armor of the First Amendment, this interest in self-identification through marriage deserves the kind of judicial protection implicit in the Zablocki majority's insistence on strict scrutiny of a law whose practical effect is to forbid marriage.

We have seen how the act and state of marriage are statements of identity and of identification with one's partner. This phenomenon feeds on itself; if large numbers of people equate marriage and commitment, then each successive marriage is apt to seem to the marrying couple both the symbol of commitment and the undertaking itself. The notion of marriage as a contract, long embedded in law and popular culture, conveys this dual meaning. ${ }^{210}$ Zablocki's reaffirmation of "the fundamental character of the right to marry" 11 is entirely justified.

What follows from this conclusion is just what Justice Powell apparently feared when he wrote these words in his Zablocki concurrence:

State regulation [of marriage] has included bans on incest, bigamy, and homosexuality, as well as various preconditions to mar-

208. Justice Marshall's remark that the right to procreate "must imply some right to enter the only relationship in which the State of Wisconsin allows scxual relations legally to take place," 434 U.S. at 386 (referring to state fornication statute), surely should be taken as a rhetorical device and not a suggestion thar he really thought the couple would go to jail for going to bed.

209. One of the standard ways of presenting one's self to the world is to do so as a member of a "team." See E. Goffman, supra note 69, at 78-82. Professor Tribe has accurately commented that the values of privacy are matched by equally important "outward-looking aspects of self"; "freedom to have impact on others-to make the "statcment' implicit in a public identity-is central to any adequate conception of the self." L. TRIBE, supra note 19, at 887-88. See pp. 635-37, 653-54 supra (self-expression through intimate association).

210. In one sense, a contract is the parties' symbolic expression of assent, and in another sense, the obligation so formed. The difference between marrying and entering a futures contract for pork bellies is that the commitment reinforced by marriage is the foundation for the caring and self-identification that let us be who we are.

211. 434 U.S. at 386 . 
riage, such as blood tests. Likewise, a showing of fault on the part of one of the partners traditionally has been a prerequisite to the dissolution of an unsuccessful union. A "compelling state purpose" inquiry would cast doubt on the network of restrictions that the States have fashioned to govern marriage and divorce. ${ }^{212}$

Exactly so. The freedom of intimate association does not stop at the protection of traditional marriage against absolute bans. Properly understood, Zablocki implies a thoroughgoing reassessment of the constitutionality of a wide range of state laws limiting the right to marry and restricting other nonmarital forms of intimate association.

As Justice Powell remarked, once we recognize the duty of government to offer substantial justification for restrictions on the freedom of intimate association, conditions on the termination of marriage come under similar scrutiny. Divorce, like marriage, is a statement about oneself, and about one's future commitments. As the Court remarked in Boddie v. Connecticut, ${ }^{213}$ the filing-fee case, acquiring one's "single" associational status may be valued not only in its own right but also as the key to remarriage, and thus to all the values that make marriage a "fundamental" interest. To condition divorce on a showing of fault is to place an insuperable burden on some spouses, and thus, as in Zablocki itself, to interfere very significantly with such a spouse's decision to associate with another person in marriage. If statutes prohibiting bigamy are valid-a proposition that seems debatable on principle but acceptable as a prediction of decisions for the near term ${ }^{214}$-then no-fault divorce seems implied by the freedom of intimate association, unless the state can demonstrate some very strong interest in the fault requirement. ${ }^{215}$ Similarly, the Court's cavalier use of the minimum-rationality standard to test a long residence requirement conditioning access to the divorce court ${ }^{216}$ must

212. Id. at 399 (Powell, J., concurring).

213. 401 U.S. 371,376 (1971).

214. In a descriptive sense, Professor Tribe seems correct in saying that laws forbidding polygamy are "secure" against constitutional attack. L. TRIBE, supra note 19 , at 946 n.19A.

215. Professor Blumberg has pointed out to me that in a state whose law gives husbands control over marital property, a fault requirement for divorce does have the virtue of giving wives some badly needed bargaining power on termination of marriage. Given the Supreme Court's recent reluctance to find constitutional flaws in even the most grievous state-promoted economic inequalities, it is probably too much to expect the equal protection clause to provide any near-term relief against the unfairness of such a state's marital property law. Surely, however, that sort of response is the preferred long-range solution to the problem, rather than the submergence of the freedom of intimate association.

219. See pp. 657.58 supra. 
surely be reconsidered in the light of the strength of the associational values at stake in such a case.

Obviously, some prohibitions on marriage will survive even the closest judicial scrutiny. Age restrictions, for example, can be seen as promoting the principle of associational choice, when the age of auttonomy is set low enough. The choice to marry requires not only intellectual capacity but the maturity to appreciate something of the nature of the commitment one is making. Similarly, incest laws forbidding parent-child marriage are arguably sustainable even when the child is mature, on the theory that parental authority established during one's childhood may have a lasting impact, dominating what would otherwise be the child's freedom of choice. ${ }^{217}$ But what shall we make of the recent tragic case in which a brother and sister, who had grown up in separate adoptive families without knowing of each other's existence, found each other as adults, loved each other, and married? What the Commonwealth of Massachusetts made of it was a crime. The couple pleaded guilty and were convicted of incest, fined $\$ 100$ each and placed on probation. 218

If every outright prohibition on marriage must pass the test of strict judicial scrutiny-and it must-then to justify such laws we must search for a state interest of very great importance. To the extent that an incest law is designed to protect against the weakening of society's gene pool, this case is an inappropriate one for asserting the interest; the couple had already decided, before they were hailed into court by the woman's adoptive parents, that they would not have children and that the man would have a vasectomy. To the extent that incest laws may have grown out of a concern to promote social integration by forcing intimate associations to be made across family lines, that concern surely cannot have the same strength in today's highly mobile, urbanized and often anonymous society as it had in the small communities in which the taboo was first invented. There remains the state's interest in promoting a moral view. That is generally a valid concern, but as I have argued in connection with the prohibition on homosexual conduct, there is no legitimacy in an effort by the state to advance one view of morals by preventing the expression of another view. ${ }^{219}$ Some independent harm must justify the restriction

217. Because parent-child incest appears to be a worldwide taboo, no doubt it originates in something other than a universal appreciation of the principle of associational choice. The point of the statement in the text is that the taboo seems generally consistent with the choice principle. Of course, the choice principle is no charter for the type of brother/sister incest that involves, for example, a brother and a much younger sister who is bullied into giving her consent.

218. Los Angeles Times, July 2, 1979, at 13, col. 1; Time, July 2, 1979, at 76.

219. See pp. 657-58 supra. 
on that expression-and that turns us back to concerns about genetics and about socially ingrown families. ${ }^{220} \mathrm{I}$ do not expect any court in this country-today or in the foreseeable future-to hold that the Constitution protects the freedom of a brother and sister to marry. The reason, however, lies not in principle but in the force of conventional morality as a political constraint on principle's coherent development. ${ }^{221}$

\section{B. Comparable Nonmarital Relationships}

Rebecca was a librarian, and Fred a custodian, at a public library in Pennsylvania. Although Fred was married, the couple began to see each other outside working hours. When Rebecca became pregnant with Fred's child, Fred left his wife and moved in with Rebecca. While they "did not conceal their arrangement, neither did they advertise it." 222 Members of the community complained, and the library board tried to persuade Fred and Rebecca to stop living together. When they refused, they were fired. In Hollenbaugh v. Carnegie Free Library, ${ }^{23}$ they brought suit in federal district court against the library for declaratory and injunctive relief and for damages. The court rejected their equal protection argument, concluding that the board's decision to fire them satisfied the demands of minimum rationality; the court of appeals affirmed on the district court's opinion. The Supreme Court denied certiorari, over the recorded dissent of Justices Brennan and Marshall.224

What the library board objected to, it seems, was the openness of the couple about their relationship. The board did not want to appear to condone their "affair," as they characterized the relationship, or the birth of the child outside marriage. Justice Marshall cited a number of the Court's recent decisions upholding the constitutional "freedom of personal choice in matters of marriage and family life,"225 and then added this statement of things to come:

220. It is not enough to say, as Justice Powell said in his concurrence in Zablocki, that the state can ensure "that its rules of domestic relations reflect the widely held values of its people." 434 U.S. at 399.

221. See pp. 690-92 infra.

222. Hollenbaugh v. Carnegie Free Library, 439 U.S. 1052, 1053 (1978) (Marshall, J., dissenting from denial of certiorari).

223. 436 F. Supp. 1328 (W.D. Pa. 1977), aff'd mem., 578 F.2d 1374 (3d Cir.), cert. denied, 439 U.S. 1052 (1978).

224. 439 U.S. 1052 (1978). Justice Marshall criticized the denial of certiorari partly on the ground that the circuits appear to be in conflict on the principal issue in the case, and partly on the basis of the error of the courts below in using a minimum rationality standard of review. His opinion deserves careful reading, for it almost certainly represents the direction in which constitutional law will move, following the lead of a rapidly growing body of nonconstitutional law.

225. Id. at 1055 (quoting Cleveland Bd. of Educ. v. LaFleur, 414 U.S. 632, 639 (1974)). 
Petitioners' rights to pursue an open rather than a clandestine personal relationship and to rear their child together in this environment closely resemble the other aspects of personal privacy to which we have extended constitutional protection. That petitioners' arrangement was unconventional or socially disapproved does not negate the resemblance, particularly in the absence of a judgment that the arrangement so offends social norms as to evoke criminal sanctions. ${ }^{226}$

Justice Marshall's emphasis on the right to pursue an open relationship is a clear recognition of the importance of the associational value of self-identification. His analogizing of this case to decisions protecting personal choice as to marriage, procreation and pregnancy, contraception and abortion, and family living arrangements is a similar, if implicit, recognition of the substantive values that link the various forms of intimate associational choice. More immediately, of course, his analysis offers protection for the choice to live together in intimacy without marrying. 227

A couple's decision to live together without marrying does not, in the ordinary case, represent the same degree of commitment as does the decision to marry. Yet the commitment implicit in such a decision, while it may be tentative, is not trivial. In fact, if the couple see their living arrangement as a trial marriage, it takes on something of the instrumental quality the Griswold Court saw in sexual privacy. There is responsibility in any significant emotional involvement, ${ }^{228}$ and the values of society, caring, intimacy and self-identification are all strongly implicated in such a case. As the decisions cited by Justice Marshall in Hollenbaugh show, we are already well on our way to assimilating the live-together couple into much of our constitutional doctrine protecting marriage and the traditional family. ${ }^{229}$ The more serious questions concerning marriage-like relationships do not concern laws forbidding fornication or adultery, which largely go unenforced in any event, but the conditioning of various benefits on marital status, or on the termination of unmarried cohabitation.

Justice Stevens, concurring in Zablocki, made two related comments

226. 439 U.S. at $1055-56$ (citations omitted). He noted that the state had repealed its laws penalizing adultery and fornication in 1972 . Id. at 1054 .

227. Justice Marshall's throw-away line about the absence of a law prohibiting fornication or adultery should by no means be taken as an endorsement of the constitution. ality of such laws, in application either to enduring sexual relationships or to casual ones. Cf. Note, Fornication, Cohabitation, and the Constitution, 77 MICH. L. REv. 252 (1978).

228. See H. LYND, supra note 43 , at $237 \mathrm{n}$.

229. There is irony here, because the statutory abandonment of common law marriage generally has been hailed as an adyanced, "modern" thing for a legislature to do. 
that can serve as a point of analytical departure: (1) "A classification based on marital status is fundamentally different from a classification which determines who may lawfully enter into the marriage relationship." ${ }^{230}$ (2) "When a State allocates benefits or burdens, it may have valid reasons for treating married and unmarried persons differently." ${ }^{231}$ The Jobst decision exemplifies both these statements. ${ }^{232}$

Let us carry that case one step further. Suppose that the Social Security law did not cut off the child's dependency benefit when his surviving mother remarried, but did cut it off when she had a man, not her husband, living in the house. The Supreme Court decided King $v$. Smith, ${ }^{233}$ an analogous case involving welfare benefits, by interpreting the federal statute to exclude this result. If such a case were to arise today, and if the statutory construction ground were unavailable, surely the Court would follow the lead of Justice Douglas's concurrence in the welfare case, holding the attempted regulation of the mother's morals unconstitutional. Some classifications based on marital status, in other words, are constitutionally unwarranted.234

Eisenstadt $v$. Baird ${ }^{235}$ dealt with such a classification, and properly understood spells not only the eventual adoption of the views of Justice Marshall in Hollenbaugh, but the eventual demise of fornication statutes. Courts other than the Supreme Court have reached similar conclusions, often on nonconstitutional grounds, when public officials have sought to deny various benefits to persons who engage in nonmarital sex or unmarried cohabitation. ${ }^{236}$ It is not accidental that

230. 434 U.S. at $403-04$.

231. Id. at 403 .

232. A different case would be presented if the law terminated the child's benefits upon the marriage of his mother. The distinction lies in the relative predictability that the two post-marriage living arrangements will provide support for the child; the. new husband of the mother normally will have no legal obligation to support the child. Absent a strong likelihood of such support, a court would be reluctant to tolerate visiting this sort of penalty on the mother's decision to remarry. An analogous penalty on the child's marriage was present in Jobst, but was offset by the general expectation of spousal support as a replacement for the lost benefit.

233. 392 U.S. 309 (1968).

234. The Fourth Circuit thus missed the mark in Ensminger v. Commissioner, 610 F.2d 189 (4th Cir. 1979). In that case, a man claimed a dependency deduction for his support of a woman who lived with him but was not his wife. I.R.C. $\$ 152(b)(5)$ dis. allows such a deduction when the relationship is "in violation of local law," and in this case the relationship violated North Carolina's cohabitation statute. The court concluded that it was rational for Congress to defer to state law on such questions. Characterizing the burden on any associational freedom to be "indirect," and citing Califano v. Jobst, 434 U.S. 47 (1977), the court refused even to consider the asserted invalidity of the state statute on which the denial of the deduction was based. 610 F.2d at 194.

235. 405 U.S. 438 (1972).

236. This trend is exemplified in decisions of lower federal courts, e.g., Shuman v. City of Philadelphia, 470 F. Supp. 449 (E.D. Pa. 1979) (police officer cannot be fired for refusing to answer questions about his unmarried cohabitation); Fisher v. Snyder, 
most of these cases involve the claims of women. ${ }^{237}$ Eisenstadt itself is correctly seen as a case involving the status of women. The extension of the freedom of intimate association beyond marriage to associations such as a couple's living together can be seen in a similar egalitarian light.

\section{Legitimacy of Parentage}

The Supreme Court has had more than a decade of experience in testing the validity, under the equal protection clause, ${ }^{238}$ of laws drawing distinctions on the basis of the status of illegitimacy. ${ }^{239}$ Doctrinal discussion in this stream of cases has centered on the selection of the appropriate standard of review. To this day, the Court continues to stagger from one position to another on the question. If there is a center to this crooked doctrinal path, it is this: "Although . . . classifications based on illegitimacy are not subject to 'strict scrutiny,' they nevertheless are invalid under the Fourteenth Amendment if they are not substantially related to permissible state interests." 240 Along the Court's sliding scale of standards of review, that one stands somewhere between the minimum-rationality standard and the intermediate standard used to test sex discrimination. ${ }^{241}$

When the Court explains why the standard of review is heightened at all for classifications based on illegitimacy, it usually says that it is unfair to disadvantage someone for a status beyond her control and bearing no relation to her ability to contribute to society. Further, says the Court, to punish a child "to express society's disapproval of the parents' liaisons 'is illogical and unjust." "242 It is both inefficient

346 F. Supp. 396 (D. Neb. 1972), aff'd, 476 F.2d 375 (8th Cir. 1973) (school teacher cannot be fired for having man stay overnight with her), and state courts as well, e.g., In re Burrell, 58 Ohio St. 2d 37, 388 N.E.2d 738 (1979) (mother's unmarried cohabitation does not justify removing children from her custody); Cord v. Gibb, _ Va.

254 S.E.2d 71 (1979) (woman cannot be denied admission to bar under "good moral character" standard merely because she lives with man who is not her husband).

237. Antinepotism regulations also tend primarily to disadvantage women because it is more frequently the case that the male relative is the one already employed, and the female relative the job-seeker.

238. By this phrase $I$ mean to include the equal protection component of the due process clause of the Fifth Amendment.

239. The cases began with Levy v. Louisiana, 391 U.S. 68 (1968) (state cannot prevent illegitimate children from suing for wrongful death of their mother).

240. Lalli v. Lalli, 439 U.S. 259, 265 (1978).

241. Since Craig v. Boren, 429 U.S. 190, 197 (1976), gender discrimination has been said to be unconstitutional unless it is "substantially related" to achieving "important governmental objectives."

242. Mathews v. Lucas, 427 U.S. 495,505 (1976) (quoting Weber v. Aetna Cas. \& Sur. Co., 406 U.S. 164, 175 (1972)). 
and unfair, says the Court, to seek to promote legitimate family relationships by imposing sanctions on illegitimate children.

Inequality is, indeed, at the heart of the problems presented by these cases, and the Court's explanations have force; there is every reason to scrutinize carefully any asserted justification for inequality between legitimate and illegitimate children. More generally, however, there is equal reason to scrutinize the inequality between persons in traditional marriage/family relationships and those in other comparable forms of intimate association. The issues presented by the status of illegitimacy cannot be separated from its wider institutional context. This is one cluster of cases in which the freedom of intimate association serves its organizing function best by permitting us to see, not just the way associational values come into play in a particular case, but the way an entire institutional system seriously impairs those values.

Some notion of legitimacy of parentage appears in virtually all societies. The underlying assumption is that a child needs a male link to the rest of the community. Thus it is the "sociological father" who transmits his status or wealth to his children, and especially to his sons. ${ }^{243}$ Rose and Lewis Coser have theorized that the likelihood of deviance from the principle increases when a particular social subgroup has little stake in transmitting status from fathers to sons-as where the fathers, as a group, lack wealth and status-or in a society that emphasizes achievement (and correspondingly deemphasizes ascription) in awarding status. ${ }^{244}$ On this theory, it should come as no surprise that the highest rates of illegitimacy in our own society are found among the nonwhite poor, or that a general questioning of the concept of illegitimacy should follow in the wake of an egalitarian political movement. The recognition of social diversity in family organization, including the recognition of "women-headed households as alternative or secondary norms rather than forms of disorganization," "245 should, in time, lead to changes in our assumptions about

243. See Coser \& Coser, The Principle of Legitimacy and Its Patterned Infringement in Social Revolutions, in Cross-National. Family Research 119 (M. Sussman \& B. Cogswell eds. 1972). Malinowski called this social invention the "Principle of Legitimacy," and declared it to be universal. Malinowski, Parenthood, the Basis of Social Structure, in The FAmily: Its Structure \& Functions 51 (R. Coser ed., 2d ed. 1974). Deviation from the principle, in this view, does not detract from its universality, because the principle retains its normative force and the deviation is seen as a departure from the norm. Coser \& Coser, supra, at 119-21.

244. Coser \& Coser, supra note 243, at 119-21.

245. Adams, An Inquiry into the Nature of the Family, in Family in Transition, supra note 24 , at 72,82 . 
the legal status of informal unions-and in particular the status of unmarried mothers and their children.

Whatever may be the case in other societies, the Anglo-American law of illegitimacy surely derives from two interrelated purposes of our institutional progenitors. First, imposing bastardy's disabilities on a child was seen, in significant part, as a punishment visited on his parents for their sin. ${ }^{240}$ Even more importantly, the idea of legitimacy of parentage served a system of male control over economic resources. Since the notion of bastardy-as-punishment chiefly took effect in rules disabling illegitimate children from making claims against their fathers' estates, and since formal marriage was the only basis for a woman's right to inherit from the man who fathered her children, the punishment in question was reserved for unmarried women and their children. The unmarried father, far from being punished, was strengthened in his power to dispose of his property. The canonists may have invented the rules of marriage and legitimacy, but those rules found ready acceptance in the temporal courts ${ }^{2 \pm 7}$ because they served to assure that a man's status and wealth would attach to a woman only when he chose to formalize their union, and would pass only to the children of such a formal union. As we shall see, these themes are modern as well as medieval.

In the perspective of the freedom of intimate association, the constitutional basis for the whole system of legitimacy/illegitimacy is shaky. If it is "illogical and unjust" to visit condemnation on a child for her parents' "liaisons," it is absurd to condemn the child of a union that is itself constitutionally protected. ${ }^{248}$ What the freedom of intimate association supplies to our analysis of the illegitimacy cases is an awareness that unwed parents and their children form intimate associations nourishing the same substantive values we seek in families based on formal marriage. It follows that any significant impairment of those associational values must be justified, in proportion to the impairment, by state interests that are at least as substantial, achieved by means that do not unduly restrict the associational freedom. It also follows that if there are other ways to achieve the state interests in question without so impairing the values of intimate as-

246. See 2 F. Pollock \& F. Maitland, supra note 118 , at 376 .

247. Id. at 377 .

248. Perhaps another generation of judges will be able to avoid words like "liaisons." The ugly word "illegitimacy" will probably survive the demise of the legal status that gave it currency, but even there we can have hopes. The fact that I use the word here is a measure of my own socialization; perhaps another generation of academics will not choose to avoid being awkward by being offensive. 
sociation, the state has failed to carry its burden of justification..$^{249}$

Given the origins of our law's illegitimacy concept in the control of status and property, it was foreseeable that the Supreme Court's decisions in this field typically would deal with property relationships on the death of the father-that is, with inheritance or entitlements to survivors' benefits under wrongful death statutes or social welfare legislation. Arguably, the latter claims are stronger, since they are generally based on a theory of compensation or need, while an illegitimate child's inheritance is something entirely in the control of the father. The question our legislators must face is this: What shall we do when the father of an illegitimate child has made no will, and has taken no formal action to legitimate his child? Should the law's inertial weight lean in favor of the illegitimate child's claim, or against it? Writing for a plurality in Lalli v. Lalli, ${ }^{250}$ Justice Powell characterized the goal of a state law governing this question as providing for "the just and orderly disposition of property at death." ${ }^{251}$ When the dust settled, though, the order and justice that emerged had a familiar look, offering protection for fathers' estates against the claims of illegitimate children.

The Lalli case involved the claim of two illegitimate children to share in their father's intestate estate. Under state law, such a child was entitled to inherit only if, during the father's lifetime, a judicial order had been obtained declaring his paternity. The children offered to prove, by affidavits, that their father had often acknowledged openly that they were his children; he had also executed a notarized document referring to one of the children as "my son" and consenting to the son's marriage. Since the father's paternity had not been declared in a court order, however, his illegitimate children were not entitled to a share in his estate. A bare majority of the Supreme Court upheld the validity of this scheme.

Justice Powell's plurality opinion, with its emphasis on the importance of minimizing post-death litigation about the disposition of property, is a useful reminder of the historic origins of the law of illegitimacy. A man can father a child outside marriage, can acknowledge the child openly and often, and can reduce that acknowledgment to a formally executed document; the child is disinherited, though, unless someone brings a judicial proceeding-an event which

249. See generally Wallach \& Tenoso, A Vindication of the Rights of Unmarried Mothers and Their Children: An Analysis of the Institution of Illegitimacy, Equal Protection, and the Uniform Parentage Act, 23 U. KAN. L. REv. 23 (1974).

250. 439 U.S. 259 (1978).

251. Id. at 268 . 
is least likely in the very case in which father and child are closest. The reason for this statutory scheme, and presumably for the Supreme Court majority's acceptance of it, is not the principle that the father is entitled to choose his intimate associations-he had done that, in acknowledging his children-but the stability of property relationships.

On the facts of Lalli, it was not the father who was protected by the law, but his formally married widow, who successfully repulsed the claims of his acknowledged children of an informal union. Yet the estate planners who wrote the law ${ }^{252}$ surely understood what they were doing. By design, the law's inertia was to lean against the children of informal unions, and in favor of formally married women and their children. A seventeenth century probate lawyer would have no trouble in appreciating what his contemporaries have done.

If Lalli validated an ancient tradition of domination through control over status and wealth, Parham v. Hughes, ${ }^{253}$ decided four months later, validated the tradition of the illegitimacy relation as punishment for sin. An illegitimate child was killed in an auto accident. Under state law his mother would have been entitled to wrongful death damages for his death, but she was killed in the same accident. If the father had legitimated the child, in the mother's absence he would have been entitled to recover similar damages; since he had not done so, he was barred from bringing a wrongful death action. It was undisputed that the father had signed the child's birth certificate, had supported the child and had visited him regularly; the child had taken the father's name. The majority Justices differed marginally in their approach to the father's claim of sex discrimination, but fundamentally made the same response: it is often harder to prove paternity than it is to prove maternity; in any case, all the father had to do was to file a petition to legitimate his son during the son's lifetime, and he would have been entitled to damages from the son's wrongful death. ${ }^{254}$

The dissent was premised on the lack of justification for the statute's sex discrimination, and I find that argument persuasive. The perspective of the freedom of intimate association, however, is independently useful in analyzing the Parham case. The state's argument-that the father is, in effect, merely being required to live with his own associational choice-ignores the facts of the case before the Court and rests on a dubious assumption about popular understanding of the

252. See id. at 269 \& n.7.

253. 441 U.S. 347 (1979).

254. Id. at 353.57 (plurality opinion of Stewart, J.); see id. at 359.61 (Powell, J., con. curring). 
law of illegitimacy. In this case, the father's paternity simply was not in dispute. Viewed in context, the father's behavior seems also to typify the behavior of many devoted fathers of illegitimate children. ${ }^{255}$ Unless the father is unusually sophisticated, he is unlikely to know that signing a birth certificate, giving the child his name, and continuing to support him and to see him regularly are insufficient to make the parent-child relationship a real one in the eyes of the law. $\mathrm{He}$ is behaving as a father behaves; the child, the mother and the world see him as the father; he is the father, even though he has not taken the one formal step the state considers necessary to entitle him to wrongful death damages.

It seems probable that the state law was aimed at "promoting a legitimate family unit," and "setting a standard of morality"-as the state court said it was. ${ }^{250}$ The Parham dissenters, focusing on the case's sex discrimination aspect, said that since mothers were entitled to recover wrongful death damages on the death of their illegitimate children, it was plain that the state's concern for morality was being selectively promoted, along lines of distinction marked by gender. But the freedom of intimate association demands justification at a prior point in the state's-interest argument. What justifies the state's prescription of legitimacy of parentage in the first place? What justifies its preference for a morality that centers on the formality of marriage or the filing of a petition for legitimation? Four members of the majority said, "It is . . . neither illogical nor unjust for society to express its 'condemnation of irresponsible liaisons beyond the bounds of marriage' by not conferring upon a biological father the statutory right to sue for the wrongful death of his illegitimate child." 257 The father, in other words, should be ashamed of himself.

It was just this sort of reasoning that the Supreme Court rejected more than a decade earlier, in Glona \%. American Guarantee \& Liability Insurance $C_{0 .}{ }^{258}$ The mother of an illegitimate child, the Court held, could not constitutionally be denied the right to bring a wrongful death action. The fact that the legislature was "dealing with 'sin," "259 said Justice Douglas for the Court, could not justify such an arbitrary discrimination. Glona, it is true, presented the claim of a mother, not

255. Most fathers of illegitimate children surely are not so devoted, but neither have they signed their children's birth certificates, supported them, and so on.

256. See the quotations from the Georgia Supreme Court's opinion, $241 \mathrm{Ga}$. 198, 200, 243 S.E.2d 867, 869-70 (1978), in Justice White's dissent, 441 U.S. at 362.

257. 441 U.S. at 353 .

258. 391 U.S. 73 (1968).

259. 391 U.S. at 75. 
a father, and mothers of illegitimate children have been the historic victims of the system of illegitimacy in a way that fathers have not. But Parham involved a father who not only sired a child but was a father to him.

The Glona case could not be explained as resting on a theory of judicial protection of persons (such as illegitimate children) who were simply born into their status and had no responsibility for it. The opinion in Glona was very short; yet Justice Douglas's reference to "sin" carries the germ of an important constitutional idea: the freedom of intimate association. What was protected in Glona was not merely the claim of a mother, but the status of the intimate relationship between a mother and her son. The arbitrariness in the law was its discrimination based on the status of illegitimacy, its assumption that significant incidents of the parent-child relationship can be denied in the absence of a formal marriage between the child's father and mother. Seen in this light, some substantial justification for the law's discrimination is demanded by the freedom of intimate association. If Glona teaches anything, it is that the required justification is not to be found in the state's wish to punish a particular form of intimate association as "sin." We are still some distance from the day when the Supreme Court will explicitly hold that the status of illegitimacy itself is constitutionally defective, ${ }^{260}$ but when that day arrives, Glona will be waiting to serve as precedent.

\section{Homosexual Relationships}

By now it will be obvious that the freedom of intimate association extends to homosexual associations as it does to heterosexual ones. All the values of intimate association are potentially involved in homosexual relationships; all have been impaired, in various ways, by governmental restrictions on homosexual conduct and on persons who are deemed to be homosexuals. ${ }^{261}$ Although the tendency of both legislation and judicial decisions is toward decriminalization of homosexual conduct ${ }^{262}$ and greater acceptance of the capacity of homo-

260. Michael Perry has argued persuasively that this result follows from the sort of reasoning the Court is already using to heighten judicial scrutiny of classifications based on illegitimacy, i.e., the unfairness of treating illegitimate children as moral inferiors. See Perry, Modern Equal Protection: A Conceptualization and Appraisal, 79 Colum. L. REv. 1023, 1056-60 (1979). My own analysis has been influenced importantly by the work of Aleta Wallach and Patricia Tenoso, Wallach \& Tenoso, supra note 249.

261. The word "deemed" is used advisedly, to suggest the extremely complicated problem of defining the category of homosexual persons. See Rivera, supra note 190, at 800-04.

262. See note 190 supra. 
sexuals to be parents, professionals, and public employees, Rhonda Rivera's recent analysis of the legal status of homosexuals convincingly shows that a long road remains to be traveled before the freedom of intimate association is fully effectuated in this area of human relations. ${ }^{203}$

Despite the depressing length of the catalogue of remaining restrictions on homosexuals, the fact is that the enforcement of these restrictions is anything but thorough. ${ }^{264}$ The middle-class homosexual couple have each other's society, including whatever sort of sexual intimacy they want; they care for each other, and they are committed to each other, in the degree they choose. What the governmental restrictions chiefly deny them is the dignity of identification as persons and equal citizens, and certain kinds of material benefits such as employment. These two interests are interrelated, both in microcosm and in macrocosm. For the homosexual individual, it is typically the very act of self-identification that results in the loss of a material benefit. ${ }^{205}$ For avowed homosexuals as a group, as their numbers grow so will public acceptance of their status, and the inclination to restrict their opportunities will decline.

One additional issue deserves consideration: the question of homosexual marriage. ${ }^{206}$ In one view, the denial of state recognition for homosexual marriage raises a simple problem of sex discrimination: Jenny is free to marry Arthur, but Lance is not. ${ }^{207}$ For all its abstract symmetry, such a mechanical view of the issue is unhelpful. What makes a miscegenation law invalid, after all, is not merely that it classifies on the basis of race, but that it is designed to promote white supremacy. ${ }^{268}$ Surely there is no comparable implication of male inferiority in a rule limiting a man's choice of marriage partners to females. In the case of a lesbian marriage, however, it is arguable that historic assumptions about the need for a male-headed nuclear

263. Rivera, supra note 190.

264. See note 116 supra. In practical terms, a middle-class homosexual couple need not fear either criminal or civil sanctions so long as they keep their relationship and their sexual preference to themselves. In the case of homosexuality, governmental efforts to enforce a particular view of sexual morality tend to focus on those who openly avow their departure from that view, see p. 658 supra, and, as in the cases of birth control and abortion, on the poor, see Rivera, supra note 190 , at 822 n.135.

265. Rivera, supra note 190 , at $822-25$.

266. See id. at 874-78; Kennedy, Transsexualism and Single Sex Marriage, 2 ANGLo-AM. L. REv. 112 (1973); Veitch, The Essence of Marriage-A Comment on the Homosexual Challenge, 5 AngLo-Am. L. REv. 41 (1976); Note, The Legality of Homosexual Marriage, 82 YALE L.J. 573 (1973).

267. See Note, supra note 266, at 583-88 (arguing proposed Equal Rights Amendment would invalidate laws denying marriage to homosexuals).

268. Loving v. Virginia, 388 U.S. 1 (1967). 
family play some role in the state's withholding of recognition of the relationship. ${ }^{269}$ And, by extension, it is arguable that the denial of marriage to homosexual men similarly supports the traditional nuclear family, with its potential for maintaining male domination..$^{270}$

Even this more sophisticated sex discrimination argument seems a makeweight, however; the heart of the constitutional problem lies in the freedom of intimate association. What homosexuals lack is a formalized legal status that recognizes their union and commitment. Such a status would mean not only that they would have the same opportunity as heterosexual couples to make the public self-identifying statements implicit in marriage, but also that the state recognized their status as an acceptable one in society rather than one deserving of stigma. ${ }^{271}$

To the extent that material benefits turn on marital status, the denial of homosexual marriage also implies the loss of those benefits. It is no answer to the claim of equal protection in such a case to say that "marriage" implies a heterosexual union; if government makes marriage the key to some benefit, and then denies that key to couples whose unions serve all the values of intimate association except the possibility of procreation, then government has the burden of justifying the limitation of benefits to heterosexual unions-which, after all, may not produce children. While this burden is not so heavy as the burden of justifying total prohibition of homosexual relations, it is nonetheless a burden government will have a hard time meeting. ${ }^{272}$

As for the opportunity to make a formalized commitment, recognized by law, the freedom of intimate association demands some important justification for the state's offering the marital status to heterosexuals and denying any comparable status to homosexuals. The

269. See Wallach \& Tenoso, supra note 249, at 27-31.

270. Id. at 23.24 \& n.5. A concern for stigma must be part of the analysis, however, because a major reason for state refusal to provide homosexuals with any institutional alternative to marriage is that it is state policy to stigmatize homosexual conduct. Because homosexuals are now denied the opportunity to formalize their commitment to each other through the symbolism of marriage, they have had to find other wass to express that commitment. Some may go through ceremonies of their own design; others may decide to execute written contracts; still others may make the joint purchase of a home the symbol of their commitment.

271. Such an alternative status was suggested in J. Golostein \& J. KaTZ, THE Famlly AND THE LAw 9 n.l (1965). See generally Note, Homosexuals' Right to Marry: A Conslitutional Test and a Legislative Solution, 128 U. PA. L. REv. 193 (1979).

272. See Richards, supra note 15. If a heterosexual union does produce children, surely there would be no constitutional impediment to the state's offering material support in recognition that the wife takes time away from work for childbirth, or that one or both spouses may have to take time away from work to care for the children while they are small. Support of this kind, of course, should similarly be available for parents who are living in homosexual unions. 
expressive aspects of marriage suggest a parallel in First Amendment doctrine. Could the state set aside a park and allow only married people to hold meetings there? Could the state constitutionally provide blue armbands to all married persons, to let them identify themselves as committed to their spouses, and deny the right to wear similar armbands to unmarried heterosexual couples or homosexual couples who chose to make a similar statement of commitment?2:3

The chief importance of the freedom of intimate association as an organizing principle in the area of homosexual relationships is that it lets us see how closely homosexual associations resemble marriage and other heterosexual associations. For doctrinal purposes, the similarity means that both sets of cases invoke the same sliding scale of justification for state interference with the association, and in particular that any effort by the state to forbid intimate homosexual association must be justified by the same sort of heroic state interests that would be necessary to justify forbidding heterosexual marriage or other forms of heterosexual association.

In this area, above all, the burden of justification is a critical issue; our governmental restrictions on homosexuals are very largely the product of folklore and fantasy rather than evidence of real risk of harm. Suppose the state had to prove that a lesbian mother, by virtue of her lesbian status alone, was unfit to have custody of her child. Suppose the state had to prove that a male homosexual teacher, by virtue of his homosexual status alone, created special risk of seduction of children assigned to his classes. ${ }^{27 t}$ Would not such empirical enter-

273. See generally Shiffrin, Government Speech (forthcoming 27 UCLA L. REv. (1980)). Because one rhetorical question invites another, the questions in the text might evoke responses along the following lines: What of those who believe in traditional heterosexual marriage? If the state offers a comparable status to homosexuals, will those traditionalists feel that their own marriage "statements" have been debased? Is it proper to force them to give their moral support (through state recognition) to unions they believe to be immoral?

To the extent that the state's offer of a status comparable to marriage is merely a way to provide an equivalency of material benefits, there is no serious harm to traditionalists. The argument about forced moral support (in the form of acceptance by the state of homosexual unions) is a stand-off. As matters now exist, homosexuals are required to give their moral support to a system that offers state recognition to heterosexual marriages but not to homosexual ones.

274. Another state interest asserted to justify a ban on homosexual teachers is that of providing appropriate role models for school children. By a 5-4 vote, the Supreme Court recently gave its blessing to a similar argument, upholding a law forbidding employment as a public school teacher of an alien who has not shown an intention to apply for American citizenship. Ambach v. Norwick, 441 U.S. 68 (1979). In an uncharacteristically feeble majority opinion, Justice Powell focused on the power of the state to use the public schools to promote attitudes toward government, particularly loyalty. Fundamentally, the problem in such cases is to sort out legitimate and illegitimate means of governmental persuasion. One attitude the state might seek to promote, for example, 
prises finally demonstrate that the operative factor in the disqualification of homosexuals in such cases was not risk of harm, but stigma? A number of writers have suggested that homosexuals fit the usual indicia of "suspectness" of legislative classification."זs Because stigma is the one "status harm"2is that is most clearly forbidden by the Fourteenth Amendment's principle of equal citizenship, ${ }^{2 \pi t}$ the results of serious constitutional inquiry in these cases are easy to predict."is That serious inquiry and those results may take a while to arrive, but arrive they surely will.

\section{E. The Family as Artifact}

When the freedom of intimate association is seen in the perspective of our recent appreciation of cultural diversity and our recent concern for equalizing the status of women, the principle extends without difficulty to family living arrangements that are alternatives to those of the traditional nuclear family, or even the extended family given a blessing-by-plurality in Moore v. City of East Cleveland. ${ }^{270}$ Jacobus tenBroek, in his masterful exposition of California's "separate, different, and unequal system of family law of the poor," 280 focused on the fact that family living arrangements among people who are poor and who are members of racial and ethnic minorities depart significantly from the traditional model of the white-middle-class nuclear family. ${ }^{2 s 1}$ One of the results of the movement for women's liberation has been the adoption of alternative living arrangements: couples

would be devotion to the principle of separation of church and state. Can anyone doubt that a law forbidding Catholics to teach in the public schools would be invalid, even if the legislature were seeking to promote that principle? $C f$. McDaniel v. Paty, 435 U.S. 618 (1978); Epperson v. Arkansas, 393 U.S. 97 (1968).

275. See, e.g., L. Tribe, supra note 19, at 944-45 n.l7.

276. Fiss, supra note 12 , at 157 .

277. See Karst, supra note 20.

278. The way in which the stigma of homosexual status feeds on itself is illustrated by the denial of security clearances on the ground that a homosexual is, by virtue of that status alone, a security risk. What makes the homosexual government official susceptible to blackmail is the fear that his status will be disclosed, and that he will lose his clearance (and thus, in many cases, his job). There would be much less for him to fear if his clearance did not depend on other officials' assumptions about his sexual preference. See McKeand v. Laird, 490 F.2d 1262, 1266 (9th Cir. 1974) (Peckham, J., dissenting). There would be nothing at all to fear if the social stigma of homoscxuality were removed. On the security clearance problem generally, see Rivera, supra note 190, at 829.37.

279. 431 U.S. 494 (1977) (plurality opinion of Powell, J.).

280. tenBroek, California's Dual System of Family Law: Its Origin, Development, and Present Status, 16 StaN. L. Rev. 257 (1964) (part one); 16 Stan. L. Rev. 900 (1964) (part two); 17 Stan. L. Rev. 614, 682 (1965) (part three).

281. tenBroek, supra note 280, at 17 STAN. L. REv. 618-20. 
living together outside marriage; single mothers with children, sometimes combining with other similar families.

In short, law or no law, a hundred familial flowers have bloomed. Families of choice, from lesbian mothers and their children to communes of the young ${ }^{282}$ and the old ${ }^{283}$ are responses to what their members often see as the failings of other familial arrangements. The risk of criminal punishment of these people for cohabitation or some other violation of "morals" statutes is near zero-and, as many have suggested, soon to be eliminated altogether by extension of now-familiar constitutional doctrine. ${ }^{284}$ More realistic is the threat of loss of some material benefit.

Measured against the freedom of intimate association, any governmental intrusion on personal choice of living arrangements demands substantial justification, in proportion to its likely influence in forcing people out of one form of intimate association and into another. The Supreme Court demanded such justification for a law denying food stamps to households composed of "unrelated" persons, and found it lacking. ${ }^{285}$ The Court made no serious search for justification beyond minimum rationality, however, when in Village of Belle Terre v. Boraas $^{280}$ it upheld a zoning ordinance designed to screen out nontraditional families and applied to six unrelated students. Justice Douglas, apparently perceiving the village ordinance as a parallel to "greenbelt" legislation or an environmental protection law, simply waved away any claim of freedom of association, asserting that the case presented no such claim.

That will not do. There are arguments, based on the village residents' own associational claims, that have more substance to them. Professor Tribe has explored those arguments and found them want-

282. See, e.g., Berger, et al., Child-Rearing Practices of the Communal Family, in F.IMLY IN Trinsition, supra note 24, at 509; Davidson, The Hippie Alternative: Getting Back to the Communal Garden, in id. at 523; Kanter, "Getting It All Together": Commumes Past, Present, Fulure, in Future of THE FAMily, supra note 162, at 311; Comment, All in the "Fanily": Legal Problems of Communes, 7 HARv. C.R.-C.L. L. Rev. 393 (1972).

283. See Hochschild, Communal Living in Old Age, in Future of the Family, supra note 162, at 299.

284. E.g., Note, supra note 227.

285. United States Dep't of Agriculture v: Moreno, 413 U.S. 528 (1973). The Court used the language of minimum rationality, but did search for arguable justifications. In United States Dep't of Agriculture v. Murry, 413 U.S. 508 (1973), the law denied food stamps to households that included persons over 18 years old who were claimed as tax dependents by nonparticipating households. The Court applied the "irrebuttable presumptions" cloctrine, and concluded that the law failed the test of rationality. Id. at 514 .

286. 416 U.S. 1 (1974). The ordinance limited land use to single-family dwellings, and defined "family" to include no more than two persons who were unrelated by blood, adoption, or marriage. Id. at 2. 
ing, in part because the village "may not be a real 'community' or 'association' at all but simply a collection of persons [with] no organic life as a center of communal perceptions and common activities."287 The problem with this argument, as Professor Tribe immediately conceded, ${ }^{288}$ is its susceptibility to manipulation through questionbegging. Presumably the residents of the village thought they were a community, and aspired to preserve some features of their community's social character. One of the points of any freedom of association must be to let people make their own definitions of community. ${ }^{280}$ Indeed, that is what the six students themselves were arguing: they wanted to make their own choices about sharing experiences, and their own decision whether a given degree of sharing could be called an "association."

Shall we decide what kinds of association to protect in the act of defining an association? Grave dangers lurk in any such approach. I doubt that the villagers' claim can be dismissed by such a means. Yet even if we assume that they have legitimate associational interests, the case is not a stand-off, any more than the case of school segregation was a simple stand-off between claims to associational freedom. ${ }^{290}$ As in cases involving competing claims to child custody, the case of the villagers and the six students in search of association requires a judicial balancing of associational and other interests. Professor Tribe may be suggesting just such interest balancing when he says the villagers lack a "communal perception." In suburban America, one does not have to associate with the neighbors very much. If the neighbors make a racket at 2:30 in the morning, that can be dealt with by other means, whether they are six students or a domestic quarrel seeking a wider stage. The associational values the villagers seek, in other words, are trivial in comparison with those at stake in, say, a commune, or a living group of two single mothers and their children.

The students in Belle Terre were, I suppose, not so intimate a group. Presumably they intended to live in the house until they finished their studies, and then to dissolve their association. Just as any constitutional protection of enduring sexual relationships can be effective only if it is extended to the choice to engage in casual ones, however, so it would be intolerable for the state to investigate the degree of intimacy or permanence of relationship among persons who

287. L. TRIBE, supra note 19 , at 979 .

288. Id. at 980 .

289. On the neighborhood as community, see M. Janowitz, The Last Half-Century 264-319 (1978).

290. See pp. 638-39 supra. 
choose to live together. Imagine the questionnaire handed by the village planners to the students who are suspected of being less intimate than lovers, more transient than the family of a junior executive of IBM.

As the Court seemingly recognized, to fence out students because they are transients would also raise other constitutional issues. ${ }^{291}$ In any case, given the geographical mobility of the typical suburban family, it would be hard to get an ordinance passed that really did penalize persons who did not intend to stay put for, say, six years. If the point of the village ordinance was to attack the problems of noise, or litter, or parked cars, there were other ways to achieve those purposes without burdening associational freedom so heavily. If, on the other hand, the ordinance was designed to attack living arrangements that did not fit the approved suburban pattern-to draw a zoning boundary as a social cordon sanitaire-then the ordinance was a direct assault on the core of the freedom of intimate association, for the purpose of saving an idealized version of family life that no longer fits even a majority of the population.

If Belle Terre's villagers were seeking to promote the values in marriage and the traditional family, they were following a well worn path. A legislature that prohibits unmarried cohabitation, or homosexual relations, or other disapproved forms of intimate association does so primarily to promote a certain view of morality, and to protect the sensibilities of those who share that view. Although the freedom of intimate association does not wholly disable government from seeking to promote majoritarian morals, just as surely the state cannot defeat every claim to the freedom of intimate association by invoking conventional moral values. Griswold, Eisenstadt, and Roe v. Wade were cases in which such invocations failed, and other decisions have followed their example.,292 With morals as with mudguards, then, "We deal not with absolutes but with questions of degree." 293 Professor Tribe is exactly on target when he says that "the power to reinforce one type of relationship must not extend to an authority to stamp out another."204

291. See 416 U.S. at 7.

292. E.g., Carey v. Population Servs. Int'l, 431 U.S. 678 (1977); Planned Parenthood of Mo. v. Danforth, 428 U.S. 52 (1976).

293. Bibb v. Navajo Freight Lines, Inc., 359 U.S. 520, 530 (1959) (Douglas, J.).

294. L. TRIBE, sutpra note 19 , at 989 . Professor Burt, in contrast, criticizes the plurality opinion in Moore v. City of East Cleveland, 431 U.S. 494 (1977), for perceiving the case "as a dispute between a 'family' and 'the state' rather than as a dispute among citizens about the meaning of 'family.'" Burt, supra note 96 , at 391 . What the freedom of intimate association demands in a case like Moore or Belle Terre is precisely that in a dis- 
Conventional morality influences the judicial process in constitutional cases in two different but related ways. First, as I have suggested, it is taken into account in developing doctrine-that is, in determining the weights to be assigned in a process of constitutional interest balancing, and particularly those on the state's-interest side of the balance. Second, the judiciary is influenced by conventional morality in assessing the relevance to a particular case of its own position in a system of separation of powers.

The Supreme Court has explicitly recognized the force of community values in shaping constitutional doctrine. In Paris Adult Theatre $I$ v. Slaton, ${ }^{295}$ the Court upheld a state-court injunction forbidding the showing of assertedly obscene films in two "adults only" theaters. One basis for the decision was the state's interest in protecting "the social interest in . . morality." ${ }^{296}$ The Court also upheld the law as an effort to preserve "the tone of the society" ${ }^{207}$ against offense. Quoting Alexander Bickel, the Court commented that "what is commonly read and seen and heard and done intrudes upon us all, want it or not." 298 One need not agree with the decision in the Paris Adult Theatre case to agree with the general proposition that the state can legitimately seek to foster a particular morality. ${ }^{299}$ On the other hand, one who agrees with Paris Adult Theatre certainly can, without inconsistency, support a number of the claims to freedom of association discussed in this Article. A state law significantly impairing intimate association-say, by prohibiting homosexual relations-goes to values that are central to one's sense of self. The freedom-of-expression values at stake in Paris Adult Theatre, while not inconsiderable, do not compare in life-determining force with the values of intimate association. The critical point in the analysis of a claim of freedom of intimate

pute among citizens about the meaning of "family," one side can command the state's apparatus to force its views on the others only when it can supply compelling justification for doing so-justification, that is, by reference to compelling purposes other than the wish to stamp out a competing vision of "family."

295. 413 U.S. 49 (1973).

296. Id. at 61 (quoting Roth v. United States, 354 U.S. 476, 485 (1957), and Chaplinsky

v. New Hampshire, 315 U.S. 568, 572 (I942)).

297. 413 U.S. at 59 .

298. Id. (quoting Bickel, On Pornography: Dissenting and Concurring Opinions, 22 Pub. Interest 25, 25-26 (Winter 1971)).

299. A law prohibiting public sex acts, for example, seems constitutionally secure. Beyond the notions of conventional morality that would inform such a law, of course, there is a strong social interest in protecting one of the core values of intimate association. Intimacy in its sexual aspects depends on the notion that sexual relations are not to be shared widely, let alone shared with a throng of passers-by. The same consideration enfeebles any claim that public sex significantly implicates the values of intimate association. Cf. Gavison, supra note 46 , at 427 (laws prohibiting public sex acts as example of legally imposed privacy). 
association, then, is not whether the state is seeking to promote a moral view, but whether the state has offered sufficient justification for a given type of impairment of intimate associational values.

Similarly, it is not useful to make a sharp distinction between state action that coerces one's intimate associational decisions and state subsidies that merely "bribe" people to adopt a favored view of morality. A state law forbidding father-daughter incest is coercive but plainly valid. By analogy to the First Amendment, however, a state subsidy in the form of a bonus to a homosexual couple if they forswear their relationship would seem constitutionally shaky. Nevertheless, the subsidy problem is a difficult one. Surely it would not have been unconstitutional had the state in Dandridge v. Williams ${ }^{300}$ abandoned its maximum-grant system in favor of a welfare scheme that provided the same added benefits for each child, however large the family might be. ${ }^{301}$ But suppose the state were to offer every woman who went to an abortion clinic a bonus of $\$ 3000$ if she agreed to forgo an abortion. This case is troublesome; state purchase of an individual's freedom of intimate associational choice ought to be as vulnerable to constitutional attack as would a state offer of a $\$ 3000$ bonus to any person under twenty-five who agrees to resign from the Unification Church or the Young Republicans. Here we reach the borderlands of the most difficult area of modern First Amendment doctrine, the "government speech" problem. ${ }^{302}$

Not only does majoritarian morality influence the shaping of constitutional doctrine; it also influences decisions that go to the judiciary's role in the system of government. A judge faced with the question of the validity of an application of a sodomy law to the private consensual behavior of adults may be excused for feeling a momentary enthusiasm for "the passive virtues." ${ }^{03}$ Surely some such notion at least partially explains the Supreme Court's summary affirmance of a lower court's decision denying an injunction against such a law's enforcement in those circumstances. ${ }^{304}$

300. 397 U.S. 471 (1970).

301. There is, $I$ assume, no constitutional defect in a system of income tax exemptions or credits tied to the number of dependent children of each taxpayer. A "baby bonus" might pass constitutional muster, so long as it were designed, like the welfare benefits or the tax exemptions, to provide assistance in meeting the predictable expenses associated with child-rearing.

302. See Shiffin, supra note 273.

303. See A. Bickel, The Least Dangerous Branch 111-98 (1962).

304. Doe v. Commonwealth's Attorney, 425 U.S. 901 (1976). These considerations may be an explanation, in the descriptive sense; they are not a justification for the Court's action. Justice Blackmun, informally answering questions of students at the UCLA School of Law a few years ago, said that such an issue has to be brought back to the 
Deciding when to decide-a highly discretionary decision in modern practice ${ }^{305}$-is only one of the occasions for influence by conventional morality over the Supreme Court's management of its institutional role. In the sodomy case, which fell within the Court's theoretically obligatory appeals jurisdiction, the institutional decision was whether to write an opinion. Even if the Court had decided to address the constitutional merits of the case, ${ }^{306}$ it still would have had a choice as to the scope of such an opinion. Assuming the Court decided to uphold the law, should it take a sweeping position about the state's interest in enforcing morals, or rest decision on a narrow ground limited to sodomy (acts that can be performed by heterosexuals as well) and ignoring the case's implication for homosexuals? Assuming the Court decided to invalidate the law, should it paint with a brush as broad as that wielded by Justice Douglas in Griswold, or should it focus closely on the particulars of this couple's apparently stable relationship? Anyone who thinks that conventional morality plays no part in such choices ignores the Court's role as an agency of government in a human society.

The freedom of intimate association is thus a useful organizing principle, not a machine that, once set in motion, must run to all conceivable logical conclusions. Nor is it an invitation to moral chaos. To say in a given case that the sovereign must keep its hands off an individual's associational choice is merely to reaffirm that moral responsibility lives in the only place it can live, the individual conscience. It is meaningless to speak of morality when there is no choice. The freedom to choose our intimates and to govern our day-to-day relations with them is more than an opportunity for the pleasures of self-expression; it is the foundation for the one responsibility among all others that most clearly defines our humanity.

Supreme Court again and again before the Court can be expected to perceive it as one that needs to be decided. He left no doubt in the minds of at least some of his audience that he was conscious of the limitations on the Court's political capital at any given moment; he linked his response to the question about the sodomy case with a reference to Roe v. Wade, 410 U.S. 113 (1973), an opinion for which the Court and Justice Blackmun individually continue to pay a price. See B. Woodward \& S. Armstrong, The BretrREN: INSIDE THE SUPREME COURT 238-40, 413-14 (1979).

305. See A. Bickel, supra note 303; Gunther, The Subtle Vices of the "Passive Virtues"A Comment on Principle and Expediency in Judicial Review, 64 ColuM. L. REv. 1 (1964).

306. The absence of any real threat of prosecution of the Doe plaintiffs suggests that the Court's affirmance might have rested on a ripeness ground. See L. TRIBE, supra note 19 , at 943 ; Gavison, supra note 46 , at $452-53 \&$ n.98. 


\title{
The Yale Law Journal
}

Volume 89, Number 4, March 1980

\author{
Alice Armitage Colburn \\ Editor-in-Chief \\ Boris Feldman \\ Note \& Topics Editor \\ Peter A. Barnes \\ Managing Editor \\ James A. Geraghty \\ Mark S. Campisano \\ Scott M. Matheson \\ Morgan J. Frankel \\ Roberta Romano \\ Kenneth T. Roth \\ R. Laird Hart \\ Note Editors \\ Robert A. Katzmann \\ James C. Snipes \\ Article \& Book Review Editors
}

William B. Beekman
Craig B. Brod
John M. Campbell
Vincent J. Chiarello
David M. Crowe
Jeffrey P. Cunard
Perry Dane
Stuart A.C. Drake
John D. Echeverria
Neil R. Ellis
Richard H. Fallon
Charles W. Fournier
Simon Friedman
Gregory P. Goeckner

\author{
Isabelle R. Gunning \\ Theodore F. Haas \\ John C. Harrison \\ Steven M. Kamp \\ Michael D. Klausner \\ Judith A. Lachman \\ Frederick M. Lawrence \\ Carol F. Lee \\ Robert L. McGlasson \\ Rachel F. Moran \\ Richard E. Neff \\ David Nimmer \\ Russell V. Randle \\ Julie A. Roin
}

Secretaries to the Editors Edna I. Scott, Pamela Willmott

\section{Student Contributors to This Issue}

William B. Beekman, A Regulatory Approach to Diversifying Commercial Television Entertainment

Jeffrey P. Cunard, Freeing Public Broadcasting from Unconstitutional Restraints

Neil R. Ellis, Zoning for the Regional Welfare

Donald K. Stockdale, Jr., An Economic and Legal Analysis of Physical Tie-Ins

Debra A. Valentine, The Logic of Secession 